\title{
Synthesis, biological activity and molecular modelling studies of tricyclic alkylimidazo-, pyrimido- and diazepinopurinediones
}

\author{
Anna Drabczyńska - Tadeusz Karcz • Ewa Szymańska • \\ Meryem Köse • Christa E. Müller • Minka Paskaleva • \\ Janina Karolak-Wojciechowska • Jadwiga Handzlik • \\ Olga Yuzlenko • Katarzyna Kieć-Kononowicz
}

Received: 12 October 2012 / Accepted: 28 February 2013 / Published online: 2 April 2013

(C) The Author(s) 2013. This article is published with open access at Springerlink.com

\begin{abstract}
Syntheses and biological activities of imidazo-, pyrimido- and diazepino[2,1-f]purinediones containing $\mathrm{N}$-alkyl substituents (with straight, branched or unsaturated chains) are described. Tricyclic derivatives were synthesized by the cyclization of 8-bromo-substituted 7-(2-bromoethyl)-, 7-(3chloropropyl)- or 7-(4-bromobutyl)-theophylline with primary amines under various conditions. Compound 22 with an ethenyl substituent was synthesized by dehydrohalogenation of 9-(2-bromoethyl)-1,3-dimethyltetrahydropyrimido[2,1-f] purinedione. The obtained derivatives (5-35) were initially evaluated for their affinity at rat $\mathrm{A}_{1}$ and $\mathrm{A}_{2 \mathrm{~A}}$ adenosine
\end{abstract}

Electronic supplementary material The online version of this article (doi:10.1007/s11302-013-9358-3) contains supplementary material, which is available to authorized users.

A. Drabczyńska • T. Karcz • E. Szymańska • J. Handzlik •

$\mathrm{O}$. Yuzlenko $\cdot$ K. Kieć-Kononowicz $(\bowtie)$

Department of Technology and Biotechnology of Drugs,

Faculty of Pharmacy, Jagiellonian University Medical College,

Medyczna 9,

30-688 Kraków, Poland

e-mail: mfkonono@cyf-kr.edu.pl

M. Köse • C. E. Müller • M. Paskaleva

PharmaCenter Bonn, Pharmaceutical Institute, University of Bonn,

An der Immenburg 4,

53121 Bonn, Germany

J. Karolak-Wojciechowska

Institute of General and Ecological Chemistry,

Technical University of Łódź, Żwirki 36,

90-924 Łódź, Poland

Present Address:

O. Yuzlenko

Department of Chemistry, City College of New York,

City University of New York, 160 Convent Avenue,

New York, NY 10031, USA receptors (AR), showing moderate affinity for both adenosine receptor subtypes. The best ligands were diazepinopurinedione $28\left(K_{\mathrm{i}}=0.28 \mu \mathrm{M}\right)$ with fivefold $\mathrm{A}_{2 \mathrm{~A}}$ selectivity and the nonselective $\mathrm{A}_{1} / \mathrm{A}_{2 \mathrm{~A}}$ AR ligand pyrimidopurinedione $35\left(K_{\mathrm{i}} \mathrm{A}_{1}=\right.$ $0.28 \mu \mathrm{M}$ and $\left.K_{\mathrm{i}} \mathrm{A}_{2 \mathrm{~A}}=0.30 \mu \mathrm{M}\right)$. The compounds were also evaluated for their affinity at human $A_{1}, A_{2 A}, A_{2 B}$ and $A_{3}$ ARs. All of the obtained compounds were docked to the $A_{2 A} A R X$ ray structure in complex with the xanthine-based, potent adenosine receptor antagonist-XAC. The likely interactions of imidazo-, pyrimido- and diazepino[2,1-f]purinediones with the residues forming the $\mathrm{A}_{2 \mathrm{~A}}$ binding pocket were discussed. Furthermore, the new compounds were tested in vivo as anticonvulsants in maximal electroshock, subcutaneous pentylenetetrazole (ScMet) and TOX tests in mice (i.p.). Pyrimidopurinediones showed anticonvulsant activity mainly in the ScMet test. The best derivative was compound 11, showing $100 \%$ protection at a dose of $100 \mathrm{mg} / \mathrm{kg}$ without symptoms of neurotoxicity. Compounds 6, 7, 8 and 14 with short substituents showed neurotoxicity and caused death. In rat tests (p.o.), 9 was characterized by a high protection index $(>13.3)$. AR affinity did not apparently correlate with the antiepileptic potency of the compounds.

Keywords Tricyclic xanthine derivatives $\cdot$ Adenosine $A_{1}$, $A_{2 A}, A_{2 B}$ and $A_{3}$ receptor affinity - Anticonvulsant activity . Molecular modelling studies

$\begin{array}{ll}\text { Abbreviations } & \\ \text { ADP } & \text { Antiepileptic Drug Development Program } \\ \text { ARs } & \text { Adenosine receptors } \\ \text { CHO } & \text { Chinese hamster ovary } \\ \text { CNS } & \text { Central nervous system } \\ \text { DMF } & \text { Dimethylformamide } \\ \text { DMSO } & \text { Dimethylsulfoxide }\end{array}$


$\left(\left[{ }^{3} \mathrm{H}\right] \mathrm{CCPA}\right) \quad\left[{ }^{3} \mathrm{H}\right] 2$-chloro- $\mathrm{N}^{6}$-cyclopentyladenosine

$\left(\left[{ }^{3} \mathrm{H}\right] \mathrm{PSB}-603\right) \quad\left[{ }^{3} \mathrm{H}\right] 8$-(4-(4-(4-chlorophenyl)piperazine1-sulfonyl)phenyl)-1-propylxanthine

$\left(\left[{ }^{3} \mathrm{H}\right] \mathrm{PSB}-11\right) \quad\left[{ }^{3} \mathrm{H}\right] 2$-phenyl-8-ethyl-4-methyl-(8R)-4,5,7, 8-tetrahydro-1 $H$-imidazo[2,1-i]purine-5-one

$\left(\left[{ }^{3} \mathrm{H}\right] \mathrm{MSX}-2\right) \quad\left[{ }^{3} \mathrm{H}\right] 1$-propargyl-3-(3-hydroxypropyl)-7methyl-8-( $m$-methoxystyryl)xanthine)

IR

MES

NINDS

NMR

PI

PDB

PSB-36

RMSD

ScMet

TLC

UV

$\mathrm{XAC}$
Infrared

Maximal electroshock

National Institute of Neurological Disorders and Stroke

Nuclear magnetic resonance

Protection index

Protein data bank

1-Butyl-3-hydroxypropyl-8-

noradamantylxanthine

Root mean square deviation

Subcutaneous pentylenetetrazol

Thin layer chromatography

Ultra-violet

Xanthine amine congener

\section{Introduction}

Adenosine, a major constituent of nucleic acids, which consists of the purine base adenine linked to the ribose moiety, has important and diverse effects on many biological processes. Some of the physiological actions of adenosine include effects on heart rate and atrial contractility, vascular smooth muscle tone, release of neurotransmitters, lipolysis, renal function and white blood cell functions $[1,2]$.

Four adenosine receptor (AR) subtypes are known, $A_{1}, A_{2 A}$, $\mathrm{A}_{2 \mathrm{~B}}$ and $\mathrm{A}_{3}$, all of which were cloned and pharmacologically characterized. The $A_{2 A}$ and $A_{2 B}$ receptors are positively coupled to adenylyl cyclase, while $A_{1}$ and $A_{3}$ adenosine receptors cause inhibition of cAMP formation. Adenosine acts via these different receptor subtypes, the affinity to which ranges from nanomolar ("high affinity" $\mathrm{A}_{1}, 3-30 \mathrm{nM} ; \mathrm{A}_{2 \mathrm{~A}}$ $1-20 \mathrm{nM}$ ) to micromolar ("low affinity" $\mathrm{A}_{2 \mathrm{~B}}, 5-20 \mu \mathrm{M}$; $\left.A_{3}>1 \mu M\right)[3,4]$. These receptors belong to the large superfamily of $G$ protein-coupled receptors [2].

Adenosine $A_{1}$ receptors are ubiquitously expressed, e.g. in the central nervous system (CNS), especially in the brain, with high levels being expressed in many regions. The distribution of adenosine $\mathrm{A}_{2 \mathrm{~A}}$ receptors is wide ranging but restricted, including lymphocytes, platelets, brain striatum, vascular smooth muscle and endothelium [2].

The prototypical antagonists of the $\mathrm{A}_{1}$ adenosine receptor are the xanthines: theophylline and caffeine. Natural xanthines are non-specific adenosine antagonists. They are not selective for any of the adenosine receptor subtypes and have low affinity for the $A_{1}$ receptor. Due to their CNS-stimulating effects, $A_{1}$ adenosine receptor selective antagonists have been proposed as cognition enhancers for the treatment of dementias, such as Alzheimer's disease. These receptors have been shown to be involved in sedative, antiseizure and anxiolytic effects. New potential indications are being discovered and investigated: in heart (for the treatment of cardiac arrhythmias and oedemas and as positive inotropic and cardiac protectants), in kidney (for oedemas and nephritis treatment), in lung (for asthma, oedema and lung protection) and in CNS (for depression, stress and coma) diseases. $\mathrm{A}_{1} \mathrm{AR}$ antagonists are being investigated as antihypertensives and potassium-saving diuretics with kidney protective effects, for the treatment of
Fig. 1 Structures and adenosine receptor binding affinities of tricyclic xanthine derivatives (I-VI); $K$ i values are given in micromolar; $h$ human, $r$ rat

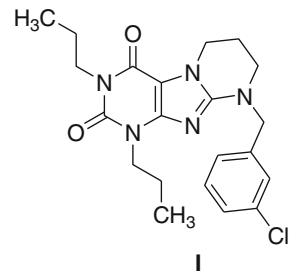

$\mathrm{rA}_{1}=0.089$
$\mathrm{rA}_{2 \mathrm{~A}}=0.478$

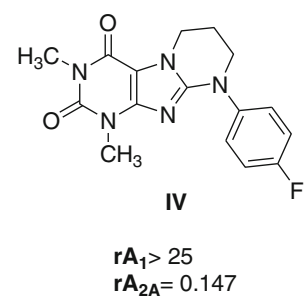

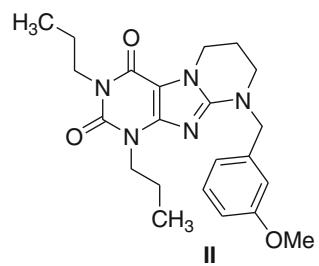

$\mathrm{rA}_{1}=0.18$

$r A_{2 A}=1.13$

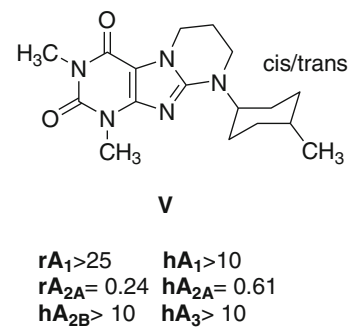

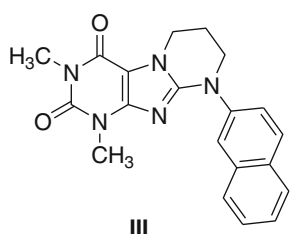

$\mathrm{rA}_{1}>25$

$\mathrm{rA}_{2 \mathrm{~A}}=0.219$

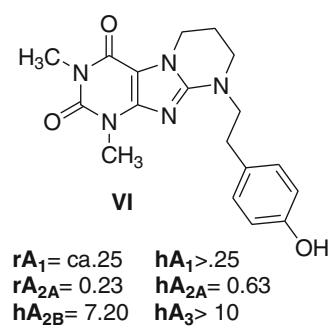


depression and asthma and for the prevention of ischemiainduced injuries [5-7].

In the last years, numerous studies have confirmed the ability of $\mathrm{A}_{2 \mathrm{~A}}$ adenosine receptor antagonists to prevent neurodegenerative diseases such as Parkinson's and Alzheimer's diseases, ischemic brain damage and, recently, epilepsy and sensorimotor disorders (restless legs syndrome-RLS) [8-14]. Methylxanthines such as theophylline and caffeine have been known to enhance locomotor activity; however, these compounds are non-selective antagonists and have weak affinity for $\mathrm{A}_{2 \mathrm{~A}} \mathrm{AR}$.

Our efforts were directed towards the development of new selective xanthine adenosine receptor ligands. Our main interest has focussed on the investigation of tricyclic xanthine derivatives [15-19]. The so far most active compounds are shown in Fig. 1. The most potent $A_{1}$ AR ligands were found among 1,3-dipropyl-substituted benzylpyrimidopurinediones (I, II) [17], while $\mathrm{A}_{2 \mathrm{~A}}$ adenosine receptor ligands were 1,3-

Table 1 Structures of the tested imidazo-, pyrimido- and diazepino[2,1-f]purinediones (5-35)<smiles>[R]N1CCn2c1nc1c2c(=O)n([R])c(=O)n1C</smiles>

\begin{tabular}{|c|c|c|c|c|c|c|c|}
\hline Cpd & $\mathbf{R}$ & $\mathbf{R}^{1}$ & n & Cpd & $\mathbf{R}$ & $\mathbf{R}^{1}$ & $\mathbf{n}$ \\
\hline 5 & $\mathrm{H}$ & $\mathrm{CH}_{3}$ & 2 & & & & \\
\hline 6 & $\mathrm{CH}_{3}$ & $\mathrm{CH}_{3}$ & 2 & 22 & & $\mathrm{CH}_{3}$ & 2 \\
\hline 7 & & $\mathrm{CH}_{3}$ & 2 & 23 & & $\mathrm{CH}_{3}$ & 2 \\
\hline 8 & & $\mathrm{CH}_{3}$ & 2 & 24 & & $\mathrm{CH}_{3}$ & 2 \\
\hline 9 & & $\mathrm{CH}_{3}$ & 2 & 25 & $\mathrm{H}$ & $\mathrm{CH}_{3}$ & 3 \\
\hline 10 & & $\mathrm{CH}_{3}$ & 2 & 26 & & $\mathrm{CH}_{3}$ & 3 \\
\hline 11 & & $\mathrm{CH}_{3}$ & 2 & 27 & & $\mathrm{CH}_{3}$ & 3 \\
\hline 12 & & $\mathrm{CH}_{3}$ & 2 & 28 & & $\mathrm{CH}_{3}$ & 3 \\
\hline 13 & & $\mathrm{CH}_{3}$ & 2 & 29 & & $\mathrm{CH}_{3}$ & 3 \\
\hline 14 & & $\mathrm{CH}_{3}$ & 2 & 30 & & $\mathrm{CH}_{3}$ & 3 \\
\hline 15 & & $\mathrm{CH}_{3}$ & 2 & 31 & & $\mathrm{CH}_{3}$ & 3 \\
\hline 16 & & $\mathrm{CH}_{3}$ & 2 & 32 & & $\mathrm{CH}_{3}$ & 3 \\
\hline 17 & & $\mathrm{CH}_{3}$ & 2 & 33 & $\mathrm{H}$ & $\mathrm{CH}_{3}$ & 1 \\
\hline 18 & & $\mathrm{CH}_{3}$ & 2 & 34 & & $\mathrm{CH}_{3}$ & 1 \\
\hline 19 & & $\mathrm{CH}_{3}$ & 2 & 35 & & $\mathrm{C}_{3} \mathrm{H}_{7}$ & 2 \\
\hline
\end{tabular}


dimethyl-substituted aryl- (III, IV) [16] cycloalkyl- (V) [19] and phenalkylpyrimidopurinediones (VI) [18] (Fig. 1). Several of the most active ligands at adenosine $\mathrm{A}_{2 \mathrm{~A}} \mathrm{AR}$ (e.g. III, IV and VI) [20] were demonstrated to exhibit antiparkinsonian effects. Among pyrimidopurinediones, compounds were found which displayed anticonvulsant properties - protective activity in subcutaneous pentylenetetrazole (ScMet) or in maximal electroshock (MES) and ScMet test; however, the mechanism of this action was not clear $[16,19]$.

As a continuation of our search for potent adenosine $A_{1}$ and especially $\mathrm{A}_{2 \mathrm{~A}}$ receptor ligands among cycloalkyl annelated xanthines, we have developed a new series of imidazo-, pyrimido- and diazepino[2,1-f]purinedione derivatives possessing aliphatic substituents (open congeners of cycloalkyl derivatives) in the annelated ring, e.g. alkyl, alkynyl and alkenyl chains. The compounds turned out to be selective $A_{1}$ or $\mathrm{A}_{2 \mathrm{~A}} \mathrm{AR}$ antagonists with moderate, submicromolar affinity as shown by radioligand binding studies at native rat receptors. Investigated compounds were examined also for $\mathrm{A}_{2 \mathrm{~B}}$ and $\mathrm{A}_{3}$ AR affinity at human recombinant AR. Additionally, the most active compounds were evaluated for affinity at human recombinant $A_{1}$ and $A_{2 A} A R$ affinity. Molecular modelling studies were performed to discuss affinity of the compounds through the docking onto the active sites of the $\mathrm{A}_{2 \mathrm{~A}}$ adenosine receptor model. Investigated compounds were examined for their anticonvulsant activity as well.

\section{Results and discussion}

\section{Chemistry}

The synthesis of tricyclic imidazo-, pyrimido- and diazepinopurinediones (Table 1) was accomplished as shown in Fig. 2. As starting material for 1,3-dimethylimidazo[2,1-f]purinediones $(\mathbf{3 3}, \mathbf{3 4})$, 7-(2-bromoethyl)-8bromotheophylline (1) was used, the preparation of which had been described by Caccacae [21]. In our laboratory, a modified procedure was developed using a two-phase catalysis method [16]. The other starting compounds, 7-(3chloropropyl)-8-bromotheophylline (2) for 1,3-dimethylpyrimido[2,1-f]purinediones (5-24) and 7-(4-bromobutyl)8-bromo-theophylline (3) for 1,3-dimethyl-diazepino[2,1-f] purinediones (25-32), were obtained as previously described [22, 23]. 1,3-Dipropyl-7-(3-chloropropyl)-8-bromoxanthine (4) $[16,17]$ was used as starting material for the synthesis of pyrimido[2,1-f]purinedione (35). The cyclization reaction with amines possessing straight, branched or unsaturated chains was carried out under various conditions (excess of amine, solvent and different reaction time). The synthesis of compounds 8, 9 and 23 was described previously [24], but their structures had been confirmed only by UV spectra, and pharmacological tests had not been performed. Unsubstituted compounds 5, 25 and $\mathbf{3 3}$ were previously synthesized in our group $[25,26]$ and were now subjected to pharmacological tests to compare them with substituted derivatives. Compound $\mathbf{2 2}$ with an ethenyl moiety was obtained by dehydrohalogenation of 9-(2-bromoethyl)-1,3dimethyl-6,7,8,9-tetrahydropyrimido[2,1-f]purinedione (21) [27] (formed from the appropriate hydroxy ethyl derivative 20 [28]) with ethanolic potassium hydroxide (Fig. 2). The structures of the synthesized compounds were confirmed by UV, IR and ${ }^{1} \mathrm{H}$ NMR spectra: UV spectra showed a bathochromic shift typical for 8-aminoxanthine derivatives with $\lambda_{\max }$ of about $300 \mathrm{~nm}$ [29]. The IR absorption bands were typical of xanthine derivatives [30], and in the ${ }^{1} \mathrm{H}$ NMR spectra, the expected chemical shifts were observed. All compounds were purified by recrystallization.
Fig. 2 Synthesis of substituted imidazo-, pyrimido- and diazepino[2,1-f]purinediones. Reagents and conditions: $i$ appropriate primary amines, solvent (EtOH, n-PrOH, n$\mathrm{BuOH}, \mathrm{DMF}$ or without solvent), reflux; $i i$ aminoethanol, reflux; iii $\mathrm{PBr}_{3}$, $\mathrm{CHCl}_{3}$, reflux; iv $\mathrm{KOH}, \mathrm{EtOH}$, reflux

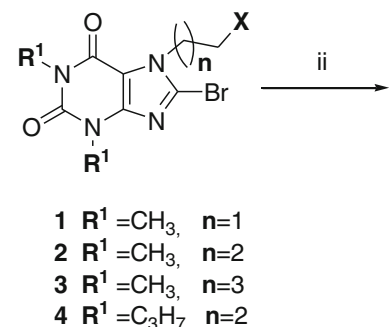<smiles>Cn1c(=O)c2c(nc3n2CCCN3CCBr)n(C)c1=O</smiles>

20

21<smiles>C=CN1CCCn2c1nc1c2c(=O)n(C)c(=O)n1C</smiles>

22 
$\mathrm{X}$-ray structure analysis

Among derivatives with various alkyl substituents at $\mathrm{N}(9)$ or (10) (Table 1), monocrystals of three of them10, 11 and 30-suitable for X-ray structure analysis could be selected. The structures represent pyrimido(10 and 11) and diazepino- (30) purinediones with $\mathrm{N} 1$, N3-dimethyl substituents at the xanthine nitrogen atoms. They feature linear (pentyl and hexyl) or branched (isopentyl) substituents at N(9) or (10). The description and discussion of 10, 11 and $\mathbf{3 0}$ spatial properties are attached in the supplementary section.
Pharmacology

All compounds were tested in vitro in radioligand binding assays for affinity to $A_{1}$ and $A_{2 A}$ adenosine receptors in rat cortical membrane and rat striatal membrane preparations, respectively. The results are presented in Table 2 . The nonselective AR ligand caffeine, selective $A_{2 A} A R$ antagonist Preladenant (SCH420814) [31] and selective $\mathrm{A}_{1} \mathrm{AR}$ antagonist PSB-36 [31, 32] were included for comparison. Examined compounds were additionally tested for affinity at human recombinant $A_{1}, A_{2 A}, A_{2 B}$ and $A_{3}$ receptors stably expressed in Chinese hamster ovary $(\mathrm{CHO})$ cells (Table 3$)$.

Table 2 Affinities of imidazo-, pyrimido- and diazepino[2,1-f]purinediones at rat $\mathrm{A}_{1}$ and $\mathrm{A}_{2 \mathrm{~A}}$ adenosine receptors

\begin{tabular}{|c|c|c|c|}
\hline Compound & $\begin{array}{l}\text { Adenosine } \mathrm{A}_{1} \text { receptor (rat brain } \\
\text { cortical membranes) vs. }\left[{ }^{3} \mathrm{H}\right] \mathrm{CCPA} \\
K_{\mathrm{i}} \pm \mathrm{SEM}[\mu \mathrm{M}](\% \text { inhibition } \pm \text { SEM } \\
\text { at } 25 \mu \mathrm{M})(n=3)\end{array}$ & $\begin{array}{l}\text { Adenosine } \mathrm{A}_{2 \mathrm{~A}} \text { receptor (rat brain } \\
\text { striatal membranes) vs. }\left[{ }^{3} \mathrm{H}\right] \mathrm{MSX}-2 \\
K_{\mathrm{i}} \pm \mathrm{SEM}[\mu \mathrm{M}](\% \text { inhibition } \pm \mathrm{SEM} \\
\text { at } 25 \mu \mathrm{M})(n=3)\end{array}$ & $\begin{array}{l}\mathrm{A}_{2 \mathrm{~A}} \mathrm{AR} \text { selectivity } \\
\mathrm{A}_{1} / \mathrm{A}_{2 \mathrm{~A}}\end{array}$ \\
\hline 5 & $>25(30 \pm 3 \%)$ & $5.22 \pm 0.90$ & $>5$ \\
\hline 6 & $>25(28 \pm 3 \%)$ & $4.30 \pm 0.67$ & $>6$ \\
\hline 7 & $\geq 25(42 \pm 1 \%)$ & $2.65 \pm 0.65$ & $>9$ \\
\hline 8 & $3.87 \pm 0.56$ & $1.29 \pm 0.18$ & 3 \\
\hline 9 & $4.32 \pm 0.40$ & $1.75 \pm 0.55$ & 3 \\
\hline 10 & $3.16 \pm 0.33$ & $3.06 \pm 1.00$ & 1 \\
\hline 11 & $2.87 \pm 0.39$ & $0.82 \pm 0.18$ & 4 \\
\hline 12 & $>25(38 \pm 1 \%)$ & $4.95 \pm 1.32$ & $>5$ \\
\hline 13 & $2.69 \pm 0.38$ & $0.87 \pm 0.03$ & 3 \\
\hline 14 & $\geq 25(40 \pm 1 \%)$ & $4.64 \pm 0.85$ & $>5$ \\
\hline 15 & $>25(19 \pm 3 \%)$ & $8.87 \pm 2.04$ & $>3$ \\
\hline 16 & $>25(30 \pm 2 \%)$ & $5.37 \pm 0.32$ & $>5$ \\
\hline 17 & $>25(21 \pm 0.3 \%)$ & $>25(37 \pm 9 \%)$ & - \\
\hline 18 & $>25(30 \pm 2 \%)$ & $2.38 \pm 0.81$ & $>11$ \\
\hline 19 & $7.69 \pm 0.57$ & $2.03 \pm 0.14$ & $>4$ \\
\hline 22 & $>25(30 \pm 5 \%)$ & $>25(47 \pm 3 \%)$ & - \\
\hline 23 & $4.40 \pm 0.42$ & $2.62 \pm 0.72$ & 2 \\
\hline 24 & $\geq 25(46 \pm 7 \%)$ & $7.40 \pm 2.52$ & $>3$ \\
\hline 25 & $>25(33 \pm 3 \%)$ & $>25(38 \pm 9 \%)$ & - \\
\hline 26 & $2.24 \pm 0.90(71 \pm 2 \%)$ & $1.73 \pm 0.41$ & 1 \\
\hline 27 & $1.24 \pm 0.18$ & $0.85 \pm 0.08$ & 2 \\
\hline 28 & $1.53 \pm 0.08$ & $0.28 \pm 0.02$ & 6 \\
\hline 29 & $\geqq 25(49 \pm 0 \%)$ & $3.82 \pm 0.23$ & - \\
\hline 30 & $>25(30 \pm 1 \%)$ & $3.51 \pm 1.19$ & $>7$ \\
\hline 31 & $1.33 \pm 0.22$ & $2.27 \pm 0.43$ & 0.6 \\
\hline 32 & $1.88 \pm 0.40$ & $2.26 \pm 0.79$ & 1 \\
\hline 33 & $>25(12 \pm 4 \%)$ & $>25(45 \pm 2 \%)$ & - \\
\hline 34 & $1.12 \pm 0.11(50.77 \pm 2.59 \%)$ & $3.80 \pm 1.30$ & 0.3 \\
\hline 35 & $0.28 \pm 0.02$ & $0.30 \pm 0.09$ & 1 \\
\hline Caffeine $^{[19]}$ & $18.8 \pm 5.6$ & $32.8 \pm 0.09$ & \\
\hline Preladenant (SCH420814) & $0.0687 \pm 0.0087$ & $0.000661 \pm 0.000126$ & 104 \\
\hline PSB-36 & $0.000368 \pm 0.000021$ & $0.371 \pm 0.049$ & 0.001 \\
\hline
\end{tabular}


Table 3 Affinities of imidazo-, pyrimido- and diazepino[2,1-f]purinediones at human recombinant $\mathrm{A}_{1}, \mathrm{~A}_{2 \mathrm{~A}}, \mathrm{~A}_{2 \mathrm{~B}}$ and $\mathrm{A}_{3}$ adenosine receptors

\begin{tabular}{|c|c|c|c|c|}
\hline Compound & $\begin{array}{l}\text { Adenosine } \mathrm{A}_{1} \text { receptor (human } \\
\text { recombinant) vs. }\left[{ }^{3} \mathrm{H}\right] \mathrm{CCPA} \\
K_{\mathrm{i}} \pm \mathrm{SEM}[\mu \mathrm{M}](\% \text { inhibition } \pm \\
\text { SEM at } 10 \mu \mathrm{M})(n=3)\end{array}$ & $\begin{array}{l}\text { Adenosine } \mathrm{A}_{2 \mathrm{~A}} \text { receptor } \\
\text { (human recombinant) vs. } \\
{\left[{ }^{3} \mathrm{H}\right] \mathrm{MSX}-2} \\
K_{\mathrm{i}} \pm \mathrm{SEM}[\mu \mathrm{M}](\% \text { inhibition } \pm \\
\mathrm{SEM} \text { at } 10 \mu \mathrm{M})(n=3)\end{array}$ & $\begin{array}{l}\text { Adenosine } \mathrm{A}_{2 \mathrm{~B}} \text { receptor } \\
\text { (human recombinant) vs. } \\
{\left[{ }^{3} \mathrm{H}\right] \mathrm{PSB}-603} \\
K_{\mathrm{i}} \pm \text { SEM }[\mu \mathrm{M}](\% \text { inhibition } \pm \\
\text { SEM at } 10 \mu \mathrm{M})(n=2)\end{array}$ & $\begin{array}{l}\text { Adenosine } \mathrm{A}_{3} \text { receptor } \\
\text { (human recombinant) vs. } \\
{\left[{ }^{3} \mathrm{H}\right] \mathrm{PSB}-11} \\
K_{\mathrm{i}} \pm \mathrm{SEM}[\mu \mathrm{M}](\% \text { inhibition } \pm \\
\text { SEM at } 10 \mu \mathrm{M})(n=2)\end{array}$ \\
\hline 5 & n.d. & n.d. & $>10(49 \pm 1 \%)$ & $>10(10 \pm 7 \%)$ \\
\hline 6 & n.d. & n.d. & $>10(6 \pm 2 \%)$ & $>10(3 \pm 3 \%)$ \\
\hline 7 & n.d. & n.d. & $>10(12 \pm 8 \%)$ & $>10(5 \pm 4 \%)$ \\
\hline 8 & n.d. & n.d. & $>10(1 \pm 2 \%)$ & $>10(10 \pm 3 \%)$ \\
\hline 9 & n.d. & n.d. & $>10(3 \pm 6 \%)$ & $>10(12 \pm 2 \%)$ \\
\hline 10 & n.d. & n.d. & $>10(-3 \pm 2 \%)$ & $>10(21 \pm 5 \%)$ \\
\hline 11 & $3.80 \pm 0.91$ & $2.07 \pm 0.47$ & $>10(9 \pm 5 \%)$ & $>10(39 \pm 1 \%)$ \\
\hline 12 & n.d. & n.d. & $>10(-4 \pm 3 \%)$ & $>10(8 \pm 1 \%)$ \\
\hline 13 & $1.91 \pm 0.27$ & $0.93 \pm 0.11$ & $>10(5 \pm 7 \%)$ & $>10(18 \pm 2 \%)$ \\
\hline 14 & n.d. & n.d. & $>10(-9 \pm 4 \%)$ & $>10(14 \pm 2 \%)$ \\
\hline 15 & n.d. & n.d. & $>10(0 \pm 3 \%)$ & $>10(17 \pm 1 \%)$ \\
\hline 16 & n.d. & n.d. & $>10(1 \pm 6 \%)$ & $>10(22 \pm 2 \%)$ \\
\hline 17 & n.d. & n.d. & $>10(3 \pm 7 \%)$ & $\geq 10(43 \pm 4 \%)$ \\
\hline 18 & n.d. & n.d. & $>10(-3 \pm 5 \%)$ & $>10(32 \pm 2 \%)$ \\
\hline 19 & n.d. & n.d. & $>10(0 \pm 4 \%)$ & $2.57 \pm 0.53$ \\
\hline 22 & $>10(21 \pm 7 \%)$ & $>10(29 \pm 8 \%)$ & $>10(1 \pm 3 \%)$ & $>10(11 \pm 2 \%)$ \\
\hline 23 & n.d. & n.d. & $>10(6 \pm 4 \%)$ & $>10(17 \pm 6 \%)$ \\
\hline 24 & n.d. & n.d. & $>10(29 \pm 5 \%)$ & $>10(11 \pm 2 \%)$ \\
\hline 25 & n.d. & n.d. & $>10(9 \pm 5 \%)$ & $>10(14 \pm 5 \%)$ \\
\hline 26 & n.d. & n.d. & $>10(6 \pm 5 \%)$ & $>10(12 \pm 3 \%)$ \\
\hline 27 & $2.47 \pm 0.10$ & $1.69 \pm 0.25$ & $>10(12 \pm 4 \%)$ & $>10(8 \pm 3 \%)$ \\
\hline 28 & $4.13 \pm 0.58$ & $1.10 \pm 0.16$ & $>10(10 \pm 7 \%)$ & $>10(23 \pm 3 \%)$ \\
\hline 29 & n.d. & n.d. & $>10(-4 \pm 6 \%)$ & $>10(2 \pm 4 \%)$ \\
\hline 30 & n.d. & n.d. & $>10(-1 \pm 3 \%)$ & $>10(27 \pm 0 \%)$ \\
\hline 31 & n.d. & n.d. & $>10(-1 \pm 6 \%)$ & $>10(22 \pm 3 \%)$ \\
\hline 32 & n.d. & n.d. & $>10(7 \pm 3 \%)$ & $>10(7 \pm 4 \%)$ \\
\hline 33 & n.d. & n.d. & $>10(17 \pm 8 \%)$ & $>10(9 \pm 3 \%)$ \\
\hline 34 & n.d. & n.d. & $>10(16 \pm 9 \%)$ & $>10(9 \pm 1 \%)$ \\
\hline 35 & $0.60 \pm 0.03$ & $1.39 \pm 0.21$ & $1.32 \pm 0.23$ & $0.66 \pm 0.02$ \\
\hline $\begin{array}{l}\text { Preladenant } \\
\text { (SCH420814) }\end{array}$ & $0.295 \pm 0.010$ & $0.000884 \pm 0.000232$ & $>1(25 \pm 1 \%)$ & $>1(35 \pm 1 \%)$ \\
\hline PSB-36 & $0.00397 \pm 0.00048$ & $0.332 \pm 0.034$ & $0.0486 \pm 0.0037$ & $>1(39 \pm 5 \%)$ \\
\hline
\end{tabular}

n.d. not detected

The following radioligands were used: $\left[{ }^{3} \mathrm{H}\right] 2$-chloro- $\mathrm{N}^{6}$ cyclopentyladenosine $\left(\left[{ }^{3} \mathrm{H}\right] \mathrm{CCPA}\right)$ for $\mathrm{A}_{1},\left[{ }^{3} \mathrm{H}\right] 1$-propargyl3-(3-hydroxypropyl)-7-methyl-8-(m-methoxystyryl)xanthine $\left(\left[{ }^{3} \mathrm{H}\right] \mathrm{MSX}-2\right)[33,34]$ for $\left.\left.\mathrm{A}_{2 \mathrm{~A}},{ }^{3} \mathrm{H}\right] \mathrm{PSB}-603{ }^{3} \mathrm{H}\right] 8-(4-(4-(4-$ chlorophenyl)piperazine-1-sulfonyl)phenyl)-1-propylxanthine [35] for $\mathrm{A}_{2 \mathrm{~B}}$ and $\left.{ }^{3} \mathrm{H}\right] 2$-phenyl-8-ethyl-4-methyl-(8R)-4,5,7,8tetrahydro- $1 H$-imidazo $[2,1-i]$ purine-5-one $\left(\left[{ }^{3} \mathrm{H}\right] \mathrm{PSB}-11\right)$ [36] for $\mathrm{A}_{3}$ binding studies.

Tricyclic xanthine derivatives, previously obtained in our laboratory, showed anticonvulsant activity [15-18]. Therefore, compounds 5-35 were evaluated in vivo as potential anticonvulsants by the ADP (Antiepileptic Drug Development Program of the National Institute of Neurological Disorders and
Stroke NINDS) according to the Antiepileptic Screening Project. Compounds were injected intraperitoneally as a suspension in $0.5 \%$ methylcellulose into the mice and evaluated in the preliminary screenings with at least three dose levels (30, 100 and $300 \mathrm{mg} / \mathrm{kg}$ at 0.5 - and 4-h time periods). Phase I of the evaluation included three tests: MES, ScMet seizure tests and the rotorod test for neurological toxicity (TOX). The tests were described in detail by Stables and Kupferberg [37-39].

The MES test is a model for generalized tonic-clonic seizures and identifies compounds which prevent seizure spread. The ScMet is a model to test compounds that raise seizure threshold. The minimal motor impairment was measured by the rotorod test. The results are given in Table 4 . 
Table 4 Anticonvulsant activity and neurotoxicity of imidazo-, pyrimido- and diazepino[2,1-f]purinediones in mice (i.p.)

\begin{tabular}{|c|c|c|c|c|c|c|c|c|c|c|c|c|}
\hline \multirow[t]{2}{*}{ Compound $^{\mathrm{a}}$} & \multicolumn{3}{|l|}{$\mathrm{MES}^{\mathrm{b}}$} & \multicolumn{4}{|l|}{$\mathrm{ScMet}^{\mathrm{b}, \mathrm{c}}$} & \multicolumn{4}{|c|}{ Toxicity ${ }^{b, c}$} & \multirow{2}{*}{$\begin{array}{l}\text { ASP } \\
\text { class }^{d}\end{array}$} \\
\hline & $0.25 \mathrm{~h}$ & $0.5 \mathrm{~h}$ & $1 \mathrm{~h} 4 \mathrm{~h}$ & $0.25 \mathrm{~h}$ & $0.5 \mathrm{~h}$ & $1 \mathrm{~h}$ & $4 \mathrm{~h}$ & $0.25 \mathrm{~h}$ & $0.5 \mathrm{~h}$ & $1 \mathrm{~h}$ & $4 \mathrm{~h}$ & \\
\hline 5 & & & & & & & & & & & & 3 \\
\hline 6 & & & & & & & & & $30(1 / 4) 300^{\mathrm{e}}$ & & & 4 \\
\hline 7 & & & & & $30(1 / 5)$ & & & & $300^{\mathrm{f}}(4 / 4)$ & & & 1 \\
\hline 8 & & & & & $30(1 / 5)$ & & & & $300^{\mathrm{f}}(2 / 4)$ & & & 1 \\
\hline 9 & $100(1 / 3)$ & & & & $30(1 / 4)$ & $100(4 / 5)$ & & & $\begin{array}{l}30(1 / 4) ; \\
300^{\mathrm{g}}(4 / 4)\end{array}$ & & & 4 \\
\hline 10 & $100(1 / 3)$ & & & & $300(1 / 1)$ & & & & $\begin{array}{l}100(3 / 8) ; \\
300^{\mathrm{g}}(4 / 4)\end{array}$ & & & 2 \\
\hline 11 & & & & & $100(5 / 5)$ & & & & & & & 1 \\
\hline 12 & & & & & $30(1 / 5)$ & $300^{\mathrm{h}}(1 / 5)$ & & & $30(1 / 4)$ & & & 4 \\
\hline 13 & & & & & $100(3 / 5)$ & & & & $300(2 / 4)$ & & & 1 \\
\hline 14 & & & & & $100(4 / 5)$ & & & & $300^{\mathrm{f}, \mathrm{g}}(4 / 4)$ & & & 1 \\
\hline 15 & & $100(1 / 3)$ & & & $100(5 / 5)$ & & & & $300^{\mathrm{g}}(4 / 4)$ & & & 1 \\
\hline 16 & $100(3 / 3)$ & & & & $100(5 / 5)$ & & & $100(1 / 3)$ & & & & 1 \\
\hline 17 & & & & & $300(4 / 5)$ & & $300^{\mathrm{i}}(1 / 1)$ & & $100(1 / 8)$ & & & 2 \\
\hline 18 & & & & $100(1 / 5)$ & $300(5 / 5)$ & & $300(1 / 1)$ & & & & & 1 \\
\hline 19 & & $300(1 / 1)$ & & & $30(1 / 5)$ & & & & & & & 1 \\
\hline 22 & & & & & $100(3 / 5)$ & & & & $300(1 / 4)$ & & & 1 \\
\hline 23 & & & & & & & & & $300^{\mathrm{g}}(1 / 4)$ & & & 3 \\
\hline 24 & & & & & $\mathrm{j}, \mathrm{k}$ & & & & $300^{\mathrm{g}}(4 / 4)$ & & & 3 \\
\hline 25 & & & & & & & & & & & & 3 \\
\hline 26 & & & & & & & & & $300(4 / 4)$ & & & 3 \\
\hline 27 & & & & & & & & & $300(3 / 4)$ & & & 3 \\
\hline 28 & & & & & & & & & $300^{\mathrm{f}, \mathrm{g}}(3 / 4)$ & & & 3 \\
\hline 29 & & & & & & & & & & & & \\
\hline 30 & & & & & & & & & $300(1 / 4)$ & & & 3 \\
\hline 31 & & $300(1 / 1)$ & & & $300(1 / 1)$ & & 1 & & $100(5 / 8)$ & & & 2 \\
\hline 32 & & $300(1 / 1)$ & & & & & & & $300(2 / 4)$ & & & 2 \\
\hline 33 & & & & & & & & & $300(3 / 4)^{\mathrm{f}}$ & & $300(1 / 1)^{\mathrm{g}}$ & 3 \\
\hline 34 & & & & & & & & & $\begin{array}{l}100(6 / 8)^{\mathrm{g}, \mathrm{m}} \\
300(4 / 4)^{\mathrm{k}}\end{array}$ & & $100(1 / 4)$ & 3 \\
\hline 35 & & & & & & & & & $\begin{array}{c}100(2 / 8)^{\mathrm{n}} \\
300(3 / 4)^{\mathrm{n}}\end{array}$ & & $300(2 / 2)^{\mathrm{f}}$ & \\
\hline
\end{tabular}

${ }^{\text {a }}$ Suspension in $0.5 \%$ methylcellulose

${ }^{b}$ Doses of 30, 100 and $300 \mathrm{mg} / \mathrm{kg}$. The figures in the table indicate the minimum dose whereby activity was demonstrated. The animals were examined 0.5 and $4.0 \mathrm{~h}$ after injections were made. For compounds $\mathbf{9 ,} \mathbf{1 0}$ and 16, the response was measured after $0.25 \mathrm{~h}$

${ }^{\mathrm{c}}$ In anticonvulsant tests, figures, for example, 1/5 mean number of animals protected/number of animals tested, in toxicity test — number of animals exhibiting toxicity/number of animals tested

${ }^{\mathrm{d}}$ Classification is as follows: 1 anticonvulsant activity at $100 \mathrm{mg} / \mathrm{kg}$ or less, 2 anticonvulsant activity at $300 \mathrm{mg} / \mathrm{kg}, 3$ lack of anticonvulsant activity at $300 \mathrm{mg} / \mathrm{kg}, 4$ neurotoxicity at dose $30 \mathrm{mg} / \mathrm{kg}$

${ }^{\mathrm{e}}$ Clonic seizures

${ }^{\mathrm{f}}$ Death

${ }^{\mathrm{g}}$ Unable to grasp rotorod

${ }^{\mathrm{h}}$ Tonic extension

${ }^{\mathrm{i}}$ Myoclonic jerks

${ }^{\mathrm{j}}$ Death following tonic extension

${ }^{\mathrm{k}}$ Death following clonic seizure

${ }^{1}$ Death following continuous seizure

${ }^{\mathrm{m}}$ Groaming effect

${ }^{\mathrm{n}}$ Popcorn effect 
Table 5 Anticonvulsant activity and neurotoxicity of selected compounds after oral administration (30 or $50 \mathrm{mg} / \mathrm{kg}$ ) to rats

\begin{tabular}{|c|c|c|c|c|c|c|c|c|c|c|c|}
\hline \multirow[t]{2}{*}{ Compound $^{\mathrm{a}}$} & \multicolumn{5}{|l|}{$\mathrm{MES}^{\mathrm{b}, \mathrm{c}}$} & \multicolumn{5}{|l|}{$\mathrm{ScMet}^{\mathrm{b}, \mathrm{c}}$} & \multirow{2}{*}{$\begin{array}{l}\text { Toxicity }^{\mathrm{d}} \\
0.25-4 \mathrm{~h}\end{array}$} \\
\hline & $0.25 \mathrm{~h}$ & $0.5 \mathrm{~h}$ & $1 \mathrm{~h}$ & $2 \mathrm{~h}$ & $4 \mathrm{~h}$ & $0.25 \mathrm{~h}$ & $0.5 \mathrm{~h}$ & $1 \mathrm{~h}$ & $2 \mathrm{~h}$ & $4 \mathrm{~h}$ & \\
\hline 9 & $50(4 / 4)$ & & & & & $50(4 / 4)$ & $50(4 / 4)$ & $10(2 / 4)$ & $10(2 / 4)$ & $10(3 / 4)$ & - \\
\hline 11 & & & & & & & & & $50(1 / 4)$ & & - \\
\hline 13 & $30(1 / 4)$ & & & & & $30(1 / 4)$ & & & & & - \\
\hline 15 & & & & & & $50(1 / 4)$ & $50(1 / 4)$ & $50(2 / 4)$ & $50(2 / 4)$ & & - \\
\hline 16 & $30(1 / 4)$ & & $30(1 / 4)$ & & $30(1 / 4)$ & & $50(1 / 4)$ & $50(1 / 4)$ & $50(1 / 4)$ & $50(2 / 4)$ & - \\
\hline 22 & & & & & & & $50(1 / 4)$ & $50(1 / 4)$ & & & - \\
\hline 30 & $30(2 / 4)$ & & & $30(1 / 4)$ & & & & & & & - \\
\hline
\end{tabular}

${ }^{\text {a }}$ Form-suspension in $0.5 \%$ methylcellulose

${ }^{\mathrm{b}}$ Doses of 10,30 and $50 \mathrm{mg} / \mathrm{kg}$

${ }^{\mathrm{c}}$ Figures under doses indicate number of animals protected/number of animals tested

${ }^{\mathrm{d}}$ The dash (-) indicates an absence of toxicity at maximum dose administration $(50 \mathrm{mg} / \mathrm{kg})$

Some compounds $(9,11,13,15,16,22$ and 30$)$ were also administered orally to rats and examined in the MES, ScMet screen and TOX test (Table 5). Compound 9 was tested also in the hippocampal binding model in rats to evaluate its ability to prevent or modify both the expression and acquisition of focal seizures [39] (Table 6). For two compounds (9 and 13), a quantitative test in mice (i.p.) was made $\left(\mathrm{ED}_{50}\right.$ and $\mathrm{TD}_{50}$ determination). The results of these experiments compared with literature data for valproate [40] are collected in Table 7.

\section{In vitro tests}

Synthesized tricyclic xanthine derivatives displayed affinity towards both $A_{1}$ and $A_{2 A}$ ARs in radioligand binding studies performed at rat brain membranes (Table 2). The most active but not selective $A_{1}$ AR ligand was 1,3-dipropylpyrimidopurinedione (35). In the group of diazepinopurinediones were found compounds which displayed submicromolar affinity towards adenosine $\mathrm{A}_{2 \mathrm{~A}}$ receptors. Diazepinopurinedione $28\left(K_{\mathrm{i}}=\right.$ $0.28 \mu \mathrm{M}$ ) showed moderate $\mathrm{A}_{2 \mathrm{~A}}$ AR selectivity (about sixfold). $A_{2 A}$ AR ligands with submicromolar affinity were also found among pyrimidopurinediones: compounds $\mathbf{1 1}$ and $\mathbf{1 3}$ displayed $K_{\mathrm{i}}$ values of 0.82 and $0.87 \mu \mathrm{M}$, respectively. Nsubstituted derivatives displayed higher affinity than unsubstituted analogues $(\mathbf{5}, \mathbf{2 5}$ and 33). Elongation of the straight $N$-alkyl substituents led to an increase in both $\mathrm{A}_{1}$ and $A_{2 A} A R$ affinities in the group of diazepinopurinediones.
For pyrimidopurinediones, this tendency was not so obvious; it was only observed at $A_{1} A R$. In the case of $A_{2 A} A R$, the most active ones were compounds with 6 (comp. 11) and 3 (comp. 8) atom chains. Branched $N$-alkyl, especially $\alpha$ branched substituents, generally were not favourable for AR affinity. In case of $\mathrm{A}_{1}$ AR ligands, such modifications led to a loss of affinity (compounds 12, 14, 15, 16 and 18) or its decrease (compound 19). $A_{2 A}$ AR ligands were also sensitive to these modifications; however, compounds with branched $N$-alkyl substituents still showed micromolar affinity, and $\beta$ branched derivative $\mathbf{1 3}$ was the most active one with submicromolar affinity. Enlargement of the annelated ring was favourable for both $A_{1}$ and $A_{2 A} A R$ activities. Diazepinopurinediones with the same $N$-alkyl substituents as pyrimidopurinediones were up to sixfold more potent (compounds 9 and 28, and 8 and 27). An exception here was the $N$ isopropyl derivative $\mathbf{3 4}$ which possesses a five-membered annelated ring; however, there are only two members of this group for comparison. Introduction of N1,N3dipropyl substituents into the xanthine core definitely has favourable influence on $\mathrm{A}_{1} \mathrm{AR}$ affinity of $N$ alkylpyrimidopurinediones: compound $\mathbf{3 5}$ was 15 -fold more potent than its N1,N3-dimethyl analogue 9. Ligands with unsaturated $\mathrm{N}$-substituents (22-24) displayed only moderate $\mathrm{A}_{1}$ and $\mathrm{A}_{2 \mathrm{~A}} \mathrm{AR}$ affinity.

Selected compounds are mainly those that were the most active ones at the $A_{2 A} A R(11,13,22,27,28$ and 35) and were also tested for affinity to human $A_{1}$ and $A_{2 A}$ receptors
Table 6 Test results of compound 9-preliminary hippocampal binding screen in rats (i.p)

${ }^{\mathrm{a}}$ Dose $100 \mathrm{mg} / \mathrm{kg}$

${ }^{\mathrm{b}}$ Minimal motor impairment

\begin{tabular}{|c|c|c|c|c|c|c|c|c|}
\hline \multirow[t]{2}{*}{$\mathrm{Rat}^{\mathrm{a}, \mathrm{b}}$} & \multicolumn{2}{|c|}{ Seizure pre-drug } & \multicolumn{2}{|c|}{ Score comp. 9} & \multicolumn{2}{|c|}{ After discharge pre-drug } & \multicolumn{2}{|c|}{ Duration (SCCS) } \\
\hline & Low & High & Low & High & Low & High & Low & High \\
\hline 1 & 5 & - & 0 & - & 47 & 56 & 21 & - \\
\hline 2 & 4 & 5 & 0 & - & 32 & 114 & 0 & - \\
\hline
\end{tabular}


Table 7 Quantitative anticonvulsant activity and neurotoxicity of $\mathbf{9}$ and $\mathbf{1 3}$ and valproate in mice i.p

\begin{tabular}{|c|c|c|c|c|c|}
\hline \multirow[t]{2}{*}{ Compound } & \multirow[t]{2}{*}{$\mathrm{TD}_{50}{ }^{\mathrm{a}}$} & \multirow[t]{2}{*}{$\mathrm{ED}_{50} \mathrm{MES}^{\mathrm{b}}$} & \multirow[t]{2}{*}{$\mathrm{ED}_{50} \mathrm{ScMet}^{\mathrm{c}}$} & \multicolumn{2}{|l|}{$\mathrm{PI}^{\mathrm{d}}$} \\
\hline & & & & MES & ScMet \\
\hline 9 & $137.34(184.27-222.9)$ [3.34] & $115.63(100.34-136.05)$ [8.77] & 45.19 (36.48-51.69) [9.35] & 1.19 & 3.04 \\
\hline 13 & $350.18(258.31-511.58)[5.66]$ & $>500 ; 0 ; 0$ & $94.29(67.32-126.43)$ [4.64] & $<0.7$ & 3.71 \\
\hline Valproate $^{\mathrm{e}}$ & 483 & 287 & 209 & 1.7 & 2.3 \\
\hline
\end{tabular}

${ }^{\mathrm{a}}$ Dose $(\mathrm{mg} / \mathrm{kg}$ ) eliciting evidence of minimal neurological toxicity in $50 \%$ of animals; $95 \%$ confidence interval is shown in parentheses; the slope regression line is shown in brackets

${ }^{\mathrm{b}}$ Dose $(\mathrm{mg} / \mathrm{kg})$ eliciting the MES protection in $50 \%$ animals

${ }^{\mathrm{c}}$ Dose $(\mathrm{mg} / \mathrm{kg})$ eliciting the ScMet protection in $50 \%$ animals

${ }^{\mathrm{d}}$ Protective index-neurotoxic dose (median effective dose)

${ }^{\mathrm{e}}$ Data from [40, 47]

(Table 3). Generally, the affinity at human recombinant $A_{1}$ as well as $A_{2 \mathrm{~A}}$ receptors was worse than that for native rat receptors (in the range of 1.5-threefold lower affinity). Only in the case of isobutylpyrimidopurinedione 13, the affinity for the human $A_{1} A R$ was better than that for the rat receptor and almost equal for $A_{2 A} A R$.

Affinity to the human $A_{2 B}$ and $A_{3}$ receptors of all of the investigated compounds was very weak; only the dipropyl derivative 35 showed micromolar affinity at $A_{2 B} A R$ and submicromolar affinity to the human $\mathrm{A}_{3} \mathrm{AR}$. Only one compound with a double-branched, long chain (19) from the group of dimethyl derivatives showed affinity for $\mathrm{A}_{3} \mathrm{AR}$ in the micromolar range.

Two of the most potent rat and human $\mathrm{A}_{2 \mathrm{~A}}$ receptor ligands (compounds $\mathbf{2 8}$ and $\mathbf{3 5}$ ) were investigated for their functional properties using cAMP accumulation assay. They were investigated for their potency to inhibit NECAinduced cAMP accumulation in $\mathrm{CHO}$ cells expressing the human $\mathrm{A}_{2 \mathrm{~A}}$ receptor (Fig. 3). The compounds clearly behaved as competitive antagonists as the concentration-response curve of NECA was shifted to the right in a parallel fashion in their presence. $K_{\mathrm{b}}$ values determined in living $\mathrm{CHO}$ cells expressing the human adenosine $\mathrm{A}_{2 \mathrm{~A}}$ receptor were well in accordance with $K_{\mathrm{i}}$ values determined in radioligand binding studies at membrane preparations of the same cell line. Owing to the structural similarity of all compounds in this series, we suppose that they are all antagonists.

\section{Molecular modelling studies}

In our previous molecular modelling studies on $\mathrm{A}_{1}$ and $\mathrm{A}_{2 \mathrm{~A}}$ adenosine receptors, the comparison of rhodopsin- and $\beta_{2^{-}}$ adrenergic-based homology models through the docking studies was performed [41]. Since that time, a few X-ray structures of $\mathrm{A}_{2 \mathrm{~A}} \mathrm{AR}$ in complex with various ligands have been reported in the Protein Data Bank [42, 43], among which
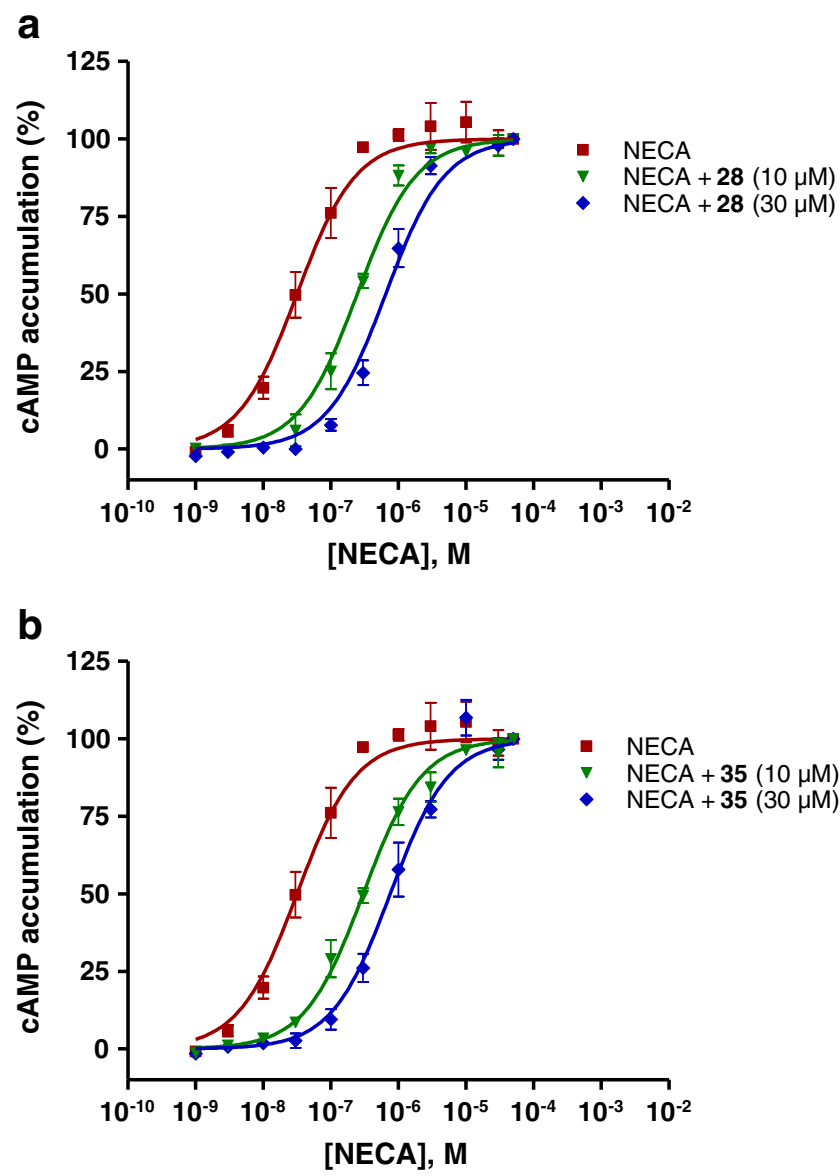

Fig. 3 cAMP accumulation studies in $\mathrm{CHO}$ cells expressing the human adenosine $\mathrm{A}_{2 \mathrm{~A}}$ receptor. The dose-response curves for the NECAinduced stimulation of cAMP accumulation were generated with NECA in the absence or in the presence of two different concentrations of 28 (a) or 35 (b). Graphs from two independent experiments performed in duplicates with mean values \pm SEM are shown. Both investigated compounds shifted the concentration-response curve for NECA in a parallel manner to the right, indicating competitive antagonism. Apparent $K_{\mathrm{b}}$ values were as follows: $1,510 \pm 20 \mathrm{nM}(\mathbf{2 8})$ and $1,210 \pm 130 \mathrm{nM}(\mathbf{3 5})$ 
those co-crystallized with xanthines: XAC (PDB code: 3REY) and caffeine (PDB code: 3RFM) are of great importance for our research. Analysis of the ligand binding mode, observed in the crystals 3 REY and 3RFM, compared to the binding mode of an inverse agonist ZM241385 bound to $\mathrm{A}_{2 \mathrm{~A}}$ AR (PDB codes: 3PWH [42] and 3EML [43]) indicates flexibility of some amino acid side chains within the receptor binding cleft. In particular, the side chain of Asn253 (6.55), described as a crucial residue for ligand binding [44-46], in $3 R E Y$ is rotated relative to other structures, e.g. 3RFM with caffeine as a ligand. Nevertheless, in both crystal structures of $\mathrm{A}_{2 \mathrm{~A}}$ AR co-crystallized with xanthines, the terminal amino group of Asn253 (6.55) forms the hydrogen bond with the same carbonyl group present in purinedione core of ligands.

Due to the structure and the size of synthesized molecules, $\mathrm{A}_{2 \mathrm{~A}}$ AR-XAC (3REY) crystal seems to be the best choice as a template for docking. To validate the utilized molecular docking methods, XAC ligand was redocked to its X-ray structure of $\mathrm{A}_{2 \mathrm{~A}}$ receptor. In case of simulation without any constraints, the obtained highest ranked pose was distinct from the one in the crystal; superposition of both conformations gave a high RMSD value of $9.68 \AA$. In this pose, an imidazol nitrogen atom of the ligand plays a role of an H-bond acceptor involved in the contact with the distal amino group of Asn253 (6.55), while a phenyl ring is situated in the proximity of TM6 and ECL2. The docking was then repeated, setting the H-bond interaction between Asn253 (6.55) and one out of carbonyl groups of the ligand as a constraint. This time, the overlay with the experimental binding mode was better (Fig. 4, RMSD= $4.53 \AA$ ). The superposition of phenylpurinedione cores was almost perfect, giving an RMSD value of $0.42 \AA$, but calculated and experimental poses differ with orientation of a polar tail of XAC. However, in the crystal structure, the position of this flexible chain is not strictly fixed, as its electron density is not complete [42]. The protocol including constrained H-bond between a ligand and Asn253 (6.55) was chosen for further docking simulations.

As an additional validation to the tested series of xanthines, the structure of caffeine was added and docked together with the rest of the compounds. Docking simulations of the set of all 30 compounds to both templates gave results that can be grouped in three clusters according to the calculated docking score values.

In the two first, highest ranked clusters, the obtained poses adopt a reflected or rotated orientation of the heterocyclic core compared to the XAC conformation from the crystal. In this position, in both cases, the carbonyl group $\mathrm{C} 2=\mathrm{O} 2$ of the purinedione interacts with a side chain amino group of Asn253 (6.55), while $\mathrm{C} 4=\mathrm{O} 4$ either corresponds to the 2oxo fragment of XAC or points to the top of the receptor, between side chains of Glu169 and Leu267 (7.32).

However, it can be noticed that in both cases of published $\mathrm{X}$-ray structures co-crystallized with xanthines, purinedione core interacts with Asn253 (6.55) in a similar way, with the same carbonyl oxygen atom $(\mathrm{C} 4=\mathrm{O} 4)$ of the ligand, even if Asn253 in this crystal acid adopts two different conformations of the side chain. Taking into account positions of both XAC and caffeine in the binding site, we can presume that the synthesized tricyclic derivatives of xanthine would bind into the $A_{2 A}$ receptor in a similar mode (shown in Fig. $5 \mathrm{a}, \mathrm{b}$ ) despite lower docking scores. For this reason, the conformations belonging to the first two clusters were rejected.

The third cluster is created by poses predicted for most of the compounds including caffeine (Fig. 5a, b). Although docking scores are lower than those for the two first sets, this pose is in agreement with the position of the ligand XAC in the crystal structure. The carbonyl group $\mathrm{C} 4=\mathrm{O} 4$ interacts here with the terminal amino group of Asn253 (6.55), and the whole purinedione core of the modelled xanthines overlies the heterocyclic part of XAC with very good RMSD values (from 0.39 to $0.93 \AA$, for caffeine $0.58 \AA$ ), making $\pi-\pi$ stacking with the aromatic part of Phe168. Two $N$-methyl (or $N$-propyl) substituents point towards the bottom of the binding site, likewise in case of XAC. The third annelated ring is situated between Phe168 and Glu169 of ECL2 from one side and Ile274 (7.39) and Met270 (7.35) from the other. The alkyl chain is buried in a similar pocket of the binding site to the phenoxy tail of XAC, in the long narrow cleft limited by residues from top fragments of TM2 (Ala63 (2.61), Ile66 (2.64) and Ser67 (2.65)) and TM7 (Leu267 (7.32) and Tyr271 (7.36)) as well as Tyr9 (1.35) (Fig. 5c).

The compounds $\mathbf{2 5}$ and 33, unsubstituted in the annelated ring, were not successfully docked in this position, while long alkyl chains in this position, branched or not, are easily adapted in the groove created by TM2 and TM7. Similarly, longer propyl fragments at 1- and 3-positions of $\mathbf{3 5}$ make hydrophobic contacts with residues Leu85 (3.33), Leu249 (6.51) and Met177 (5.38) from one side and Ile66 (2.64), Ala81 (3.29) and Val84 (3.32) from the other, increasing affinity to the receptor relative to short methyl substituents (35 vs. 9). Compounds 24 and 30 were not found among poses from this cluster either-the most probable explanation is that the linear structure of the triple bond in $\mathbf{2 4}$ or a doublebranched chain of $\mathbf{3 0}$ causes a steric clash with residues forming the cleft.

The performed docking experiments did not explain in detail the correlation between structure and $\mathrm{A}_{2 \mathrm{~A}} \mathrm{AR}$ affinity of the obtained xanthines. Nevertheless, it can be stated that both the third annelated ring and alkyl chains as $\mathrm{N}$ substituents fit well to the $A_{2 \mathrm{~A}}$ binding pocket, forming additional interactions, and their presence has a big influence on the affinity to the adenosine receptors compared to caffeine - non-selective weak $\mathrm{A}_{2 \mathrm{~A}} \mathrm{AR}$ antagonist. The similar effect is observed for two $N$-propyl substituents and the phenyl ring of XAC, very potent adenosine receptor antagonist (35, Fig. 5b). 
Fig. 4 Superposition of the XAC ligand from $3 R E Y$ crystal structure (purple) and redocked pose of XAC (orange)

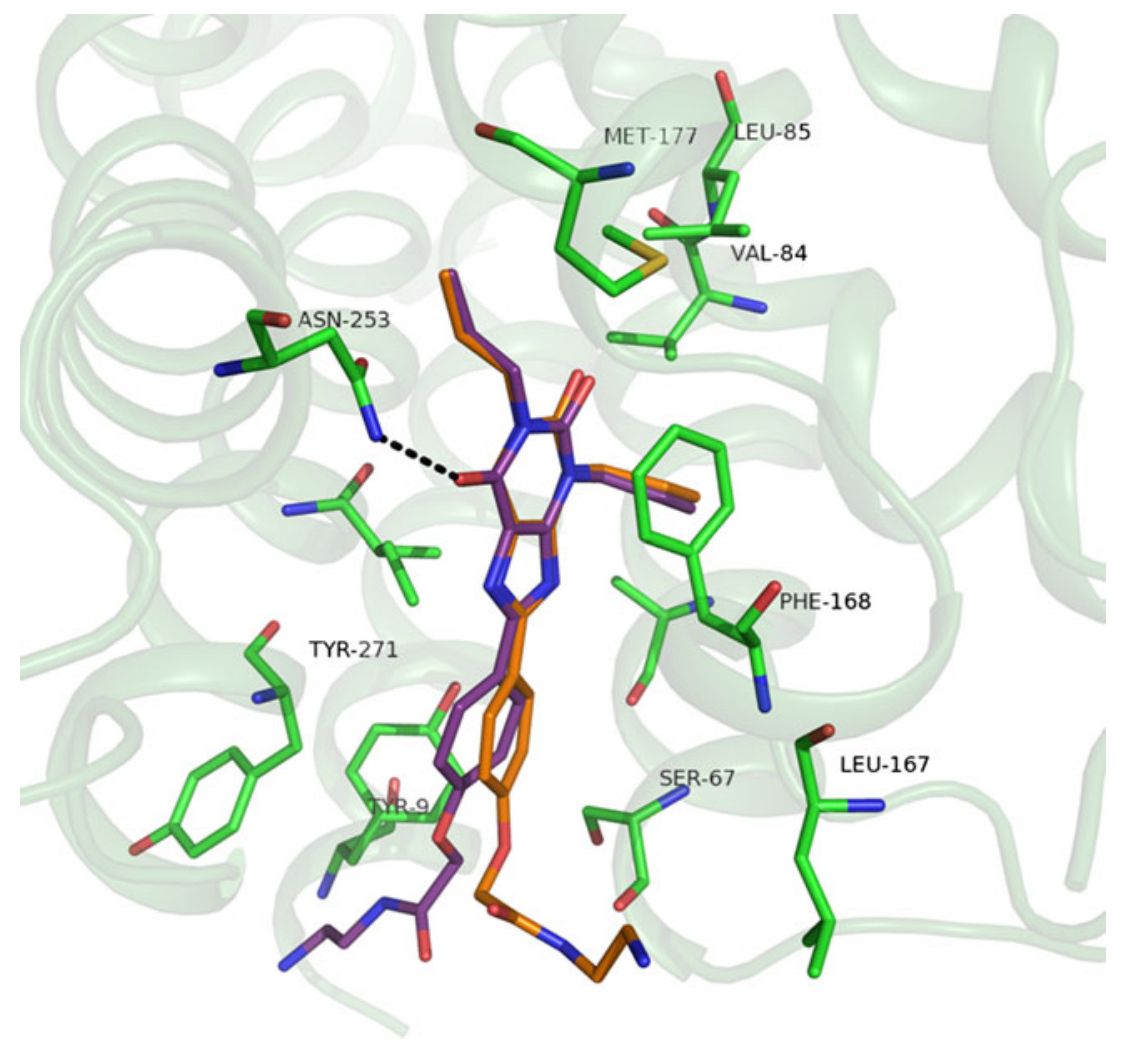

\section{In vivo tests}

Unsubstituted pyrimido- (5) and diazepinopurinedione (25) did not show protective activity in both electric and chemical seizures (Table 4). Introduction of $\mathrm{N}$-alkyl substituents resulted in anticonvulsant activity in the pyrimidopurinediones, whereas these modifications did not affect in the same way the group of diazepinopurinediones as only compounds $\mathbf{3 1}$ and $\mathbf{3 2}$ showed protective activity in a dose of $300 \mathrm{mg} / \mathrm{kg}$, but after $4 \mathrm{~h}$ caused death of tested animals. Probably, enlargement of the annelated ring in the xanthine derivatives is not favourable for anticonvulsant activity. Unsaturated substituents introduced into the tricyclic xanthine derivatives (23 and $\mathbf{2 4}$ ) were also disadvantageous. Generally, $N$-alkyl derivatives showed good protective activity in mice (i.p.), especially in ScMet test in short time $(0.5 \mathrm{~h})$. The best compound was $N$-hexylpyrimidopurinedione 11, with $100 \%$ protection at a dose of $100 \mathrm{mg} / \mathrm{kg}$ with no symptoms of neurotoxicity. The other two compounds with long lipophilic chains 18 and 19 also showed good protection: derivative 19 was active in both tests, and ligand 18 displayed protection in ScMet test. Both compounds did not show neurotoxicity. The $N$-butyl and $N$-pentyl derivatives 9 and 10 displayed protective properties in MES and ScMet tests but at the same time showed neurotoxicity. Compounds with short chains $(6,7,8$ and 14) caused death of test animals. The most toxic substance was $\mathrm{N}$ - propargylpyrimidopurinedione 24, causing death following clonic seizures and tonic extension.

The most active compounds in mice were also examined for activity in rats after oral administration, showing higher seizure protection (Table 5). The best compound was the butyl derivative 9, showing $100 \%$ protection in ScMet test in the dose of $50 \mathrm{mg} / \mathrm{kg}$ in short time $(0.25$ and $0.5 \mathrm{~h})$ and $50 \%$ protection in dose of $10 \mathrm{mg} / \mathrm{kg}$ after 12 and $4 \mathrm{~h}$. Ligand $\mathbf{1 6}$ was active in MES test at $30 \mathrm{mg} / \mathrm{kg}$ and in ScMet test at $50 \mathrm{mg} / \mathrm{kg}$. No symptoms of neurotoxicity were observed in both tested compounds. Ligand 9 was also tested in a hippocampal kindled seizure screen (Table 6). Results suggest the ability of 9 to prevent or modify fully kindled seizures. The $N$-butyl and $N$-isobutyl derivatives 9 and 13 were advanced for phase II of evaluation for quantification of activities $\left(\mathrm{ED}_{50}\right.$ and $\left.\mathrm{TD}_{50}\right)$ against MESand ScMet-induced seizures in mice (i.p.) (Table 7). These pharmacological parameters were compared with data for valproate [40, 47]. Both tested substances were characterized by a $\mathrm{PI}_{\mathrm{ScMet}}$ higher than that of valproate, but a lower PI $\mathrm{M}_{\mathrm{MES}}$.

The anticonvulsant activity of the examined compounds was analysed for correlation with AR affinity. Some coincidence of adenosine $\mathrm{A}_{2 \mathrm{~A}}$ affinity and anticonvulsant activity was observed. Compounds showing anticonvulsant activity in ScMet test $(\mathbf{9}, \mathbf{1 1}, \mathbf{1 3}, \mathbf{1 4}, \mathbf{1 5}, 16$ and 18) were among the 

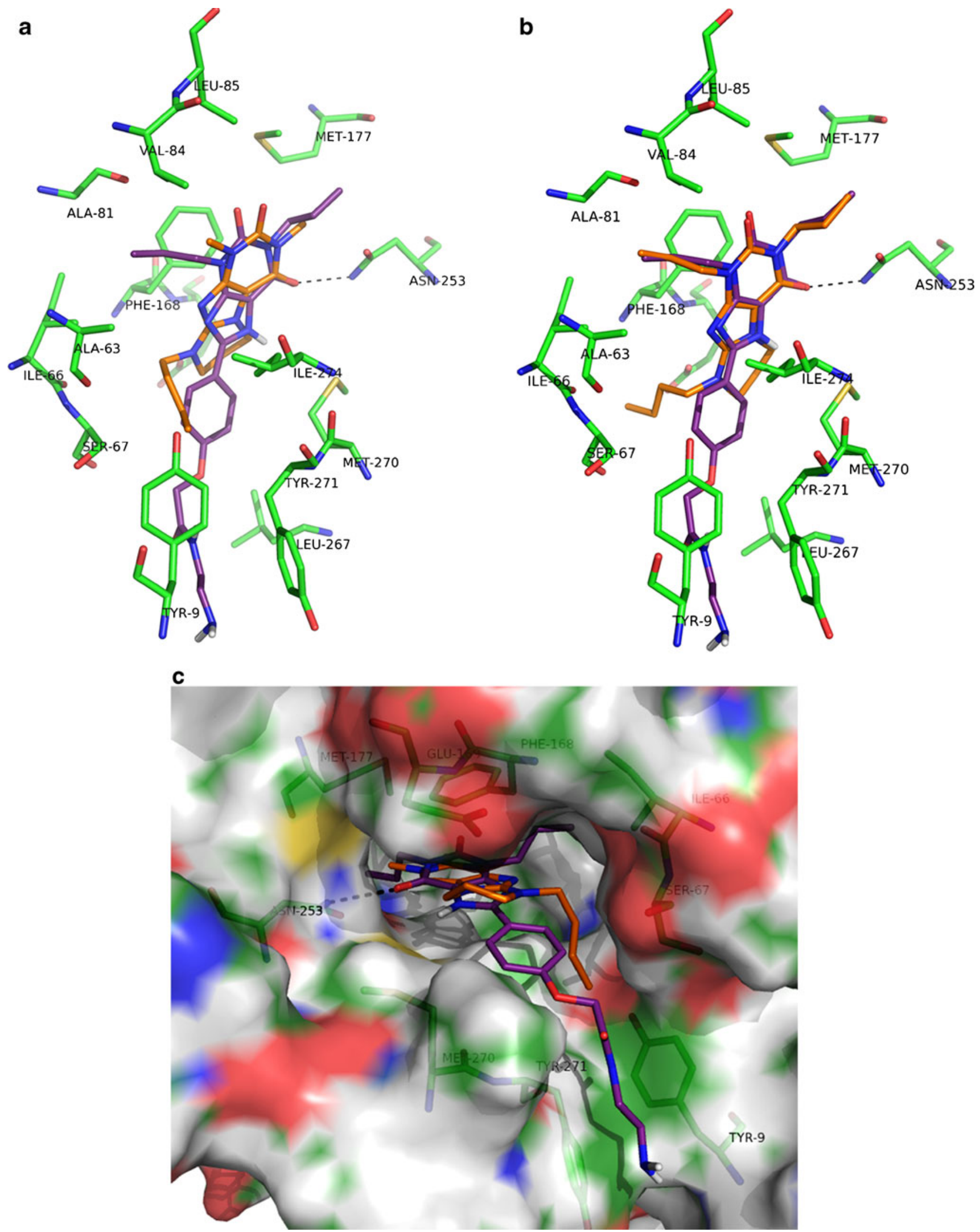

Fig. 5 a The model of compound 9 (orange) docked to 3REY crystal structure (chosen residues in green and XAC ligand in purple). b The model of compound 35 (orange) docked to $3 R E Y$ crystal structure (chosen residues in green and XAC ligand in purple). c Superposition of XAC ligand (purple) and compound 9 (orange) in the binding site of $\mathrm{A}_{2 \mathrm{~A}}$ receptor 
pyrimidinepurinedione derivatives showing affinity towards $\mathrm{A}_{2 \mathrm{~A}}$ AR. However, there were also compounds showing anticonvulsant activity but were devoid of $\mathrm{A}_{2 \mathrm{~A}} \mathrm{AR}$ affinity. The most active $\mathrm{A}_{2 \mathrm{~A}} \mathrm{AR}$ ligand, the diazepine derivative 28 and the dipropyl derivative $\mathbf{3 5}$ were not active as anticonvulsants. Comparing in vitro and in vivo activities of the studied tricyclic xanthine derivatives, there is no clear correlation between $\mathrm{A}_{1} / \mathrm{A}_{2 \mathrm{~A}} \mathrm{AR}$ affinity and anticonvulsant activity of the investigated ligands. So our previous observation that $\mathrm{A}_{2 \mathrm{~A}}$ selectivity of $\mathrm{AR}$ antagonists may be important for anticonvulsant activity has not been confirmed in the present study [19].

\section{Conclusions}

Tricyclic pyrimido- and diazepinopurinediones are moderately potent $\mathrm{A}_{1}$ and $\mathrm{A}_{2 \mathrm{~A}} \mathrm{AR}$ antagonists. Enlargement of the annelated ring caused an increase in affinity but not selectivity. Pyrimidopurinodiones showed anticonvulsant activity in mice (i.p.) and rats (p.o.), but lower homologs were toxic. Enlargement of the annelated ring was unprofitable for anticonvulsant activity and led practically to a lack of the activity. Although there is no apparent correlation between anticonvulsant activity and adenosine receptor affinity, it seems that a lipophilic substituent is necessary for both activities.

Acknowledgments The authors wish to acknowledge Professor James P. Stables for providing pharmacological data through the Antiepileptic Drug Development Program National Institutes of Health. Financial support of this research by the Ministry of Science and Higher Education and National Science Centre, Poland (grant No. 4 P05F 014 18, grant No. NN 405297836 and grant DEC-2012/04/M/ NZ4/00219) and by the BMBF, Germany (01EW0911) in the frame of ERA-NET NEURON is gratefully acknowledged. We would like to thank Mrs. Inge Renner and Katharina Thiemke for the technical assistance in the biological experiments.

Open Access This article is distributed under the terms of the Creative Commons Attribution License which permits any use, distribution, and reproduction in any medium, provided the original author(s) and the source are credited.

\section{Appendix}

Experimental section

\section{Chemistry}

Melting points were determined on a MEL-TEMP II apparatus, and they are uncorrected. IR spectra were taken as $\mathrm{KBr}$ discs on an FT Jasco IR 410 spectrometer. ${ }^{1} \mathrm{H}-\mathrm{NMR}$ spectra (in $\mathrm{CDCl}_{3}$ ) for compounds 10, 13, 14 and 22 were obtained at ambient temperature with a Bruker VM 250, for other compounds with a Varian Mercury $300-\mathrm{MHz}$ spectrometer, using signal of undeuterated solvent as an internal standard. UV spectra were recorded on a Jasco UV/Vis V530 apparatus in $10^{-5} \mathrm{~mole} / \mathrm{L}$ in methanol. Elemental analyses $(\mathrm{CHN})$ were performed on an Elementar Vario-EL III apparatus and agreed with theoretical values within $\pm 0.4 \%$. TLC data were obtained with Merck silica gel $60 \mathrm{~F}_{254}$ aluminium sheets with benzene: acetone (7:3) as developing system. Spots were detected under UV light. Syntheses of compounds $\mathbf{5}, \mathbf{2 5}$ and $\mathbf{3 3}$ were described elsewhere [25, 26].

Synthetic procedures and analytical data of tricyclic alkylimidazo-, pyrimido- and diazepinopurinediones

General procedure for the synthesis of 9-substituted 1,3dimethyl-6,7,8,9-tetrahydropyrimido[2,1-f]purine2,4(1H,3H)-dione $(\mathbf{6}-\mathbf{1 9}, \mathbf{2 3}, \mathbf{2 4})$. A mixture of $(0.66 \mathrm{~g}$, $2 \mathrm{mmol}$ ) of 7-(3-chloropropyl)-8-bromotheophylline (2) and amine derivative (4-66 mmol) was heated under reflux in the appropriate solvent (ethanol, propanol, butanol and DMF) or without solvent for 5 to $15 \mathrm{~h}$. After cooling, the precipitate was separated. If the crude compound included a little amount of unreacted 7-(3-chloropropyl)-8bromotheophylline (monitoring by TLC), it was purified by dissolving in $10 \% \mathrm{HCl}$, alkalizing to $\mathrm{pH} 8$ with $10 \% \mathrm{NaOH}$ and washing with water. If DMF was used as a reaction medium, the product was precipitated by adding water to the reaction mixture. Compound $\mathbf{1 7}$ did not crystallize after cooling and was obtained by removing the excess of 2propynylamine by steam distillation and cooling the water solution. All compounds were purified by crystallization.

\section{1,3,9-Trimethyl-6, 7,8,9-tetrahydropyrimido [2,1-f]purine-2,4(1H,3H)-dione (6)}

Reaction medium, ethanol; time of heating under reflux, $15 \mathrm{~h}$; excess of amine, 33. Crystallization with ethanol gave pure compound 6 . Yield $47 \%$, mp $251-252{ }^{\circ} \mathrm{C}$; TLC: $R_{\mathrm{f}}$ : 0.31; Anal. Calcd for $\mathrm{C}_{11} \mathrm{H}_{15} \mathrm{O}_{2} \mathrm{~N}_{5}(6)$ : C, 53.00; H, 6.07; N, 28.10. Found: C, 52.77; H, 5.91; N, 27.82. ${ }^{1} \mathrm{H}-\mathrm{NMR} \delta$ (ppm): $2.12-2.20\left(\mathrm{~m}, 2 \mathrm{H}, \mathrm{N}_{5} \mathrm{CH}_{2} \mathrm{CH}_{2} \mathrm{CH}_{2} \mathrm{~N}_{9}\right), 3.12$ (s, $3 \mathrm{H}$, $\left.\mathrm{CH}_{3}\right), 3.29-3.33\left(\mathrm{~m}, 3 \mathrm{H}+2 \mathrm{H}, \mathrm{N}_{3} \mathrm{CH}_{3}+\mathrm{CH}_{2} \mathrm{~N}_{9}\right), 3.48(\mathrm{~s}, 3 \mathrm{H}$, $\left.\mathrm{N}_{1} \mathrm{CH}_{3}\right), 4.19$ (t, $\left.J=6.04 \mathrm{~Hz}, 2 \mathrm{H}, \mathrm{N}_{5} \mathrm{CH}_{2}\right)$. IR $\mathrm{KBr}\left(\mathrm{cm}^{-1}\right)$ : 2,950-2,871- $\mathrm{CH}_{2}, 1,699-\mathrm{CO}(2), 1,655$ (4), 744- $\mathrm{CH}_{2}$. UV $\lambda_{\max }, \log \varepsilon: 300.5,4.15$.

9-Ethyl-1,3-dimethyl-6, 7,8,9-tetrahydropyrimido[2,1-f] purine-2,4(1H,3H)-dione (7)

Reaction medium, ethanol; time of heating under reflux, $5 \mathrm{~h}$; excess of amine, 29. Crystallization with ethanol (30\%) gave pure compound 7 . Yield $34 \%$, mp $215-216{ }^{\circ} \mathrm{C}$; TLC: 
$R_{\mathrm{f}}:$ 0.49; Anal. Calcd for $\mathrm{C}_{12} \mathrm{H}_{17} \mathrm{O}_{2} \mathrm{~N}_{5}$ (7): C, 54.74; $\mathrm{H}$, 6.52; N, 26.60. Found: C, 55.00; H, 6.52; N, 26.25. ${ }^{1} \mathrm{H}-$ NMR $\delta(\mathrm{ppm}): 21.22\left(\mathrm{t}, J=7.14 \mathrm{~Hz}, 3 \mathrm{H}, \mathrm{CH}_{2} \mathrm{CH}_{3}\right), 2.13-$ $2.20\left(\mathrm{~m}, 2 \mathrm{H}, \mathrm{N}_{5} \mathrm{CH}_{2} \mathrm{CH}_{2} \mathrm{CH}_{2} \mathrm{~N}_{9}\right), 3.34-3.37(\mathrm{~m}, 3 \mathrm{H}+2 \mathrm{H}$, $\mathrm{N}_{3} \mathrm{CH}_{3}+\mathrm{CH}_{2} \mathrm{~N}_{9}$ ), $3.50\left(\mathrm{~s}, 3 \mathrm{H}, \mathrm{N}_{1} \mathrm{CH}_{3}\right), 3.54-3.63(\mathrm{~m}, 2 \mathrm{H}$, $\left.\mathrm{CH}_{2} \mathrm{CH}_{3}\right), 4.20\left(\mathrm{t}, J=6.04 \mathrm{~Hz}, 2 \mathrm{H}, \mathrm{N}_{5} \mathrm{CH}_{2}\right)$. IR KBr $\left(\mathrm{cm}^{-1}\right)$ : 2,967-2,872- $\mathrm{CH}_{2}, 1,697-\mathrm{CO}(2), 1,666$ (4), 784- $\mathrm{CH}_{2}$. UV $\lambda_{\max }, \log \varepsilon: 301.5,4.28$.

\section{1,3-Dimethyl-9-propyl-6, 7,8,9-tetrahydropyrimido[2,1-f] purine-2,4(1H,3H)-dione (8)}

Reaction medium, ethanol; time of heating under reflux, $5 \mathrm{~h}$; excess of amine, 12. Crystallization with ethanol (30\%) gave pure compound 8 . Yield $60 \%$, mp $188-190{ }^{\circ} \mathrm{C}$; TLC: $R_{\mathrm{f}}: 0.52$; Anal. Calcd for $\mathrm{C}_{13} \mathrm{H}_{19} \mathrm{O}_{2} \mathrm{~N}_{5}(\mathbf{8})$ : C, $56.31 ; \mathrm{H}, 6.91$; $\mathrm{N}, 21.25$. Found: C, 56.25; H, 6.97; N, 24.96. ${ }^{1} \mathrm{H}-\mathrm{NMR} \delta$ (ppm): 0.95 (t, $\left.J=7.42 \mathrm{~Hz}, 3 \mathrm{H}, \mathrm{CH}_{2} \mathrm{CH}_{3}\right), 1.60-1.83(\mathrm{~m}, 2 \mathrm{H}$, $\mathrm{CH}_{2} \mathrm{CH}_{2} \mathrm{CH}_{3}$ ), 2.11-2.19 (m, 2H, N $\mathrm{C}_{5} \mathrm{CH}_{2} \mathrm{CH}_{2} \mathrm{CH}_{2} \mathrm{~N}_{9}$ ), 3.34 $3.46\left(\mathrm{~m}, 3 \mathrm{H}+2 \mathrm{H}, \mathrm{N}_{3} \mathrm{CH}_{3}+\mathrm{CH}_{2} \mathrm{~N}_{9}\right), 3.49-3.59(\mathrm{~m}, 2 \mathrm{H}+3 \mathrm{H}$, $\mathrm{CH}_{2} \mathrm{CH}_{3}+\mathrm{N}_{1} \mathrm{CH}_{3}$ ), 4.21 (t, J=5.91 Hz, $2 \mathrm{H}, \mathrm{N}_{5} \mathrm{CH}_{2}$ ). IR $\mathrm{KBr}$ $\left(\mathrm{cm}^{-1}\right): 2,958-2,871-\mathrm{CH}_{2}, 1,697-\mathrm{CO}(2), 1,664$ (4), 784$\mathrm{CH}_{2}$. UV $\lambda_{\max }, \log \varepsilon: 302,4.34$.

\section{9-Butyl-1,3-dimethyl-6, 7,8,9-tetrahydropyrimido[2,1-f] purine-2,4(1H,3H)-dione (9)}

Reaction medium, solvent-free; time of heating under reflux, $5 \mathrm{~h}$; excess of amine, 15. Crystallization with ethanol gave pure compound 9 . Yield $81 \%, \mathrm{mp} 174-176{ }^{\circ} \mathrm{C}$; TLC: $R_{\mathrm{f}}: 0.37$; Anal. Calcd for $\mathrm{C}_{14} \mathrm{H}_{21} \mathrm{O}_{2} \mathrm{~N}_{5}(9): \mathrm{C}, 57.71 ; \mathrm{H}$, 7.27; N, 24.04. Found: C, 57.63; H, 7.08; N, 23.84. ${ }^{1} \mathrm{H}-$ NMR $\delta$ (ppm): 0.95 (t, $\left.J=7.28 \mathrm{~Hz}, 3 \mathrm{H},\left(\mathrm{CH}_{2}\right)_{3} \mathrm{CH}_{3}\right), 1.31-$ $1.38\left(\mathrm{~m}, 2 \mathrm{H}, \mathrm{CH}_{2} \mathrm{CH}_{3}\right), 1.54-1.62\left(\mathrm{~m}, 2 \mathrm{H}, \mathrm{CH}_{2} \mathrm{CH}_{2} \mathrm{CH}_{3}\right)$, 2.09-2.17 (m, 2H, $\mathrm{N}_{5} \mathrm{CH}_{2} \mathrm{CH}_{2} \mathrm{CH}_{2} \mathrm{~N}_{9}$ ), 3.31-3.34 (m, 3H+ $\left.2 \mathrm{H}, \mathrm{N}_{3} \mathrm{CH}_{3}+\mathrm{CH}_{2} \mathrm{~N}_{9}\right), 3.48-3.53\left(\mathrm{~m}, 2 \mathrm{H}+3 \mathrm{H}, \mathrm{CH}_{2} \mathrm{CH}_{3}+\right.$ $\left.\mathrm{N}_{1} \mathrm{CH}_{3}\right), 4.19$ (t, $\left.J=6.04 \mathrm{~Hz}, 2 \mathrm{H}, \mathrm{N}_{5} \mathrm{CH}_{2}\right)$. IR $\mathrm{KBr}\left(\mathrm{cm}^{-1}\right)$ : 2,958-2,873- $\mathrm{CH}_{2}, 1,702-\mathrm{CO}(2), 1,666$ (4), 784- $\mathrm{CH}_{2}$. $\mathrm{UV} \lambda_{\max }, \log \varepsilon: 302,4.25$.

\section{1,3-Dimethyl-9-pentyl-6, 7,8,9-tetrahydropyrimido [2,1-f] purine-2,4(1H,3H)-dione (10)}

Reaction medium, solvent-free; time of heating under reflux, $5 \mathrm{~h}$; excess of amine, 20. Crystallization with ethanol ( $80 \%$ ) gave pure compound 10 . Yield $59 \%$, mp $183-185^{\circ} \mathrm{C}$; TLC: $R_{\mathrm{f}}$ : 0.43; Anal. Calcd for $\mathrm{C}_{15} \mathrm{H}_{23} \mathrm{O}_{2} \mathrm{~N}_{5}$ (10): C, 58.99; H, 7.60; N, 22.93. Found: C, 58.76; H, 7.26; N, 23.08. ${ }^{1} \mathrm{H}-\mathrm{NMR} \delta(\mathrm{ppm}): 0.92(\mathrm{t}, J=6.25 \mathrm{~Hz}, 3 \mathrm{H}$, $\left.\left(\mathrm{CH}_{2}\right)_{4} \mathrm{CH}_{3}\right), 1.27-1.65\left(\mathrm{~m}, 6 \mathrm{H},\left(\mathrm{CH}_{2}\right)_{3} \mathrm{CH}_{3}\right), 2.10-2.19$ $\left(\mathrm{m}, 2 \mathrm{H}, \mathrm{N}-\mathrm{CH}_{2} \mathrm{CH}_{2} \mathrm{CH}_{2} \mathrm{~N}_{9}\right), 3.33-3.37(\mathrm{~m}, 3 \mathrm{H}+2 \mathrm{H}$, $\left.\mathrm{N}_{3} \mathrm{CH}_{3}+\mathrm{CH}_{2} \mathrm{~N}_{9}\right), 3.46-3.54\left(\mathrm{~m}, 2 \mathrm{H}+3 \mathrm{H}, \mathrm{CH}_{2} \mathrm{CH}_{3}+\right.$ $\left.\mathrm{N}_{1} \mathrm{CH}_{3}\right), 4.24$ (t, $J=6.25 \mathrm{~Hz}, 2 \mathrm{H}, \mathrm{N}_{5} \mathrm{CH}_{2}$ ). IR $\mathrm{KBr}$ $\left(\mathrm{cm}^{-1}\right): 2,952-2,869-\mathrm{CH}_{2}, 1,699-\mathrm{CO}(2), 1,662$ (4), $784-\mathrm{CH}_{2}$. UV $\lambda_{\max }, \log \varepsilon: 301,4.34$.

9-Hexyl-1,3-dimethyl-6, 7,8,9-tetrahydropyrimido[2,1-f] purine-2,4(1H,3H)-dione (11)

Reaction medium, solvent-free; time of heating under reflux, $5 \mathrm{~h}$; excess of amine, 12. Crystallization with ethanol gave pure compound 11 . Yield $57 \%$, mp $149{ }^{\circ} \mathrm{C}$; TLC: $R_{\mathrm{f}}$ : 0.55; Anal. Calcd for $\mathrm{C}_{16} \mathrm{H}_{25} \mathrm{O}_{2} \mathrm{~N}_{5}$ (11): C, 60.16; H, 7.89; $\mathrm{N}, 21.93$. Found: $\mathrm{C}, 60.13 ; \mathrm{H}, 3.94 ; \mathrm{N}, 22.04 .{ }^{1} \mathrm{H}-\mathrm{NMR} \delta$ (ppm): 0.90 (t, $\left.J=5.77 \mathrm{~Hz}, 3 \mathrm{H},\left(\mathrm{CH}_{2}\right)_{5} \mathrm{CH}_{3}\right), 1.33-1.64$ (m, $\left.8 \mathrm{H},\left(\mathrm{CH}_{2}\right)_{4} \mathrm{CH}_{3}\right), 2.11-2.18\left(\mathrm{~m}, 3 \mathrm{H}+2 \mathrm{H}, \mathrm{N}_{3} \mathrm{CH}_{3}+\mathrm{CH}_{2} \mathrm{~N}_{9}\right)$, 3.49-3.53 (m, $\left.2 \mathrm{H}+3 \mathrm{H}, \mathrm{CH}_{2} \mathrm{CH}_{3}+\mathrm{N}_{1} \mathrm{CH}_{3}\right), 4.21(\mathrm{t}, J=$ $\left.6,04 \mathrm{~Hz}, 2 \mathrm{H}, \mathrm{N}_{5} \mathrm{CH}_{2}\right)$. IR $\mathrm{KBr}\left(\mathrm{cm}^{-1}\right): 2,952-2869-\mathrm{CH}_{2}$, $1,698-\mathrm{CO}(2), 1,664$ (4), 742- $\mathrm{CH}_{2}$. UV $\lambda_{\max }, \log \varepsilon$ : 301.5, 4.32 .

9-Isopropyl-1,3-dimethyl-6,7,8,9-tetrahydropyrimido[2,1-f] purine-2,4(1H,3H)-dione (12)

Reaction medium, propanol; time of heating under reflux, $5 \mathrm{~h}$; excess of amine, 12. Crystallization with ethanol (30\%) gave pure compound 12 . Yield $65 \%$, mp $241-242{ }^{\circ} \mathrm{C}$; TLC: $R_{\mathrm{f}}$ : 0.48; Anal. Calcd for $\mathrm{C}_{13} \mathrm{H}_{19} \mathrm{O}_{2} \mathrm{~N}_{5}$ (12): C, 56.31; H, 6.91; N, 25.25. Found: C, 56.10; H, 6.58; N, 25.05. ${ }^{1} \mathrm{H}-$ NMR $\delta$ (ppm): $1.20\left(d, J=6.86 \mathrm{~Hz}, 6 \mathrm{H}, \mathrm{CH}\left(\mathrm{CH}_{3}\right)_{2}\right), 2.05-$ $2.13\left(\mathrm{~m}, 2 \mathrm{H}, \mathrm{N}_{5} \mathrm{CH}_{2} \mathrm{CH}_{2} \mathrm{CH}_{2} \mathrm{~N}_{9}\right), 3.26$ (s, $\left.3 \mathrm{H}, \mathrm{N}_{3} \mathrm{CH}_{3}\right), 3.48$ (s, 3H, $\mathrm{N}_{1} \mathrm{CH}_{3}$ ), 4.17 (t, $J=6.04 \mathrm{~Hz}, 3 \mathrm{H}, \mathrm{N}_{1} \mathrm{CH}_{3}$ ), 4.62-4.71 (m, $\left.1 \mathrm{H}, \mathrm{N}_{9} \mathrm{CH}\right)$. IR $\mathrm{KBr}\left(\mathrm{cm}^{-1}\right): 2,967-2,848-\mathrm{CH}_{2}, 1,704$ $\mathrm{CO}$ (2), 1,662 (4), 742- $\mathrm{CH}_{2}$. UV $\lambda_{\max }, \log \varepsilon: 302,4.29$.

\section{9-Isobutyl-1,3-dimethyl-6, 7,8,9-tetrahydropyrimido[2,1-f]} purine-2,4(1H,3H)-dione (13)

Reaction medium, solvent-free; time of heating under reflux, $5 \mathrm{~h}$; excess of amine, 25. Crystallization with ethanol (50\%) gave pure compound 13 . Yield $68 \%, \mathrm{mp} 213-215^{\circ} \mathrm{C}$; TLC: $R_{\mathrm{f}}$ : 0.44; Anal. Calcd for $\mathrm{C}_{14} \mathrm{H}_{21} \mathrm{O}_{2} \mathrm{~N}_{5}$ (13): C, 57.71; H, 7.27; N, 24.04. Found: C, 58.05; H, 6.99; N, 23.79. ${ }^{1} \mathrm{H}-\mathrm{NMR} \delta(\mathrm{ppm}): 0.94(d, J=6.50 \mathrm{~Hz}, 6 \mathrm{H}$, $\left.\mathrm{CH}\left(\mathrm{CH}_{3}\right)_{2}\right), 2.01-2.19\left(\mathrm{~m}, 1 \mathrm{H}+2 \mathrm{H}, \mathrm{CH}\left(\mathrm{CH}_{3}\right)_{2}+\right.$ $\left.\mathrm{N}_{5} \mathrm{CH}_{2} \mathrm{CH}_{2} \mathrm{CH}_{2} \mathrm{~N}_{9}\right), 3.31-3.37\left(\mathrm{~m}, 2 \mathrm{H}+2 \mathrm{H}, \mathrm{CH}_{2} \mathrm{~N}_{9} \mathrm{CH}_{2}\right)$, $3.39\left(\mathrm{~s}, 3 \mathrm{H}, \mathrm{N}_{3} \mathrm{CH}_{3}\right), 3.50\left(\mathrm{~s}, 3 \mathrm{H}, \mathrm{N}_{1} \mathrm{CH}_{3}\right), 4.22(\mathrm{t}, J=$ $\left.6.00 \mathrm{~Hz}, 2 \mathrm{H}, \mathrm{N}_{5} \mathrm{CH}_{2}\right)$. IR $\mathrm{KBr}\left(\mathrm{cm}^{-1}\right): 2,964-2,844-$ $\mathrm{CH}_{2}, 1,698-\mathrm{CO}(2), 1,662$ (4), 742- $\mathrm{CH}_{2}$. UV $\lambda_{\max }$, $\log \varepsilon: 301.5,4.34$.

9-Sec-butyl-1,3-dimethyl-6, 7,8,9-tetrahydropyrimido[2,1-f] purine-2,4(1H,3H)-dione (14)

Reaction medium, solvent-free; time of heating under reflux, $5 \mathrm{~h}$; excess of amine, 25. Crystallization with ethanol 
(50\%) gave pure compound 14 . Yield $98 \%$, mp $188-190{ }^{\circ} \mathrm{C}$; TLC: $R_{\mathrm{f}}$ : 0.48; Anal. Calcd for $\mathrm{C}_{14} \mathrm{H}_{21} \mathrm{O}_{2} \mathrm{~N}_{5}$ (14): C, 57.71; H, 7.27; N, 24.04. Found: C, 57.90; H, 7.43; N, 23.87. ${ }^{1} \mathrm{H}-\mathrm{NMR} \delta(\mathrm{ppm}): 0.90(\mathrm{t}, J=7.38 \mathrm{~Hz}, 3 \mathrm{H}$, $\left.\mathrm{CH}_{2} \mathrm{CH}_{3}\right), 1.19\left(\mathrm{~d}, J=6.60 \mathrm{~Hz}, 3 \mathrm{H},=\mathrm{CHCH}_{3}\right), 2.06-$ $2.16\left(\mathrm{~m}, 2 \mathrm{H}, \mathrm{N}_{5} \mathrm{CH}_{2} \mathrm{CH}_{2} \mathrm{CH}_{2} \mathrm{~N}_{9}\right), 3.22-3.27(\mathrm{~m}, 2 \mathrm{H}$, $\left.\mathrm{CH}_{2} \mathrm{~N}_{9}\right), 3.37\left(\mathrm{~s}, 3 \mathrm{H}, \mathrm{N}_{3} \mathrm{CH}_{3}\right), 3.50\left(\mathrm{~s}, 3 \mathrm{H}, \mathrm{N}_{1} \mathrm{CH}_{3}\right)$, 4.18-4.24 (m, 2H, N $\left.\mathrm{CH}_{2}\right), 4.39-4.48\left(\mathrm{~m}, 1 \mathrm{H}, \mathrm{N}_{1} \mathrm{CH}=\right)$. IR $\mathrm{KBr}\left(\mathrm{cm}^{-1}\right)$ : 2,969-2875- $\mathrm{CH}_{2}, 1,704-\mathrm{CO}(2), 1,652$ (4), $744-\mathrm{CH}_{2}$. UV $\lambda_{\max }, \log \varepsilon: 302.5,4.26$.

\section{1,3-Dimethyl-9-(pentan-2-yl)-6,7,8,}

9-tetrahydropyrimido[2,1-f]purine-2,4(1H,3H)-dione (15)

Reaction medium, DMF; time of heating under reflux, $10 \mathrm{~h}$; excess of amine, 4. Crystallization with ethanol $/ \mathrm{H}_{2} \mathrm{O}$ gave pure compound $\mathbf{1 5}$. Yield $91 \%$, mp $143-144{ }^{\circ} \mathrm{C}$; TLC: $R_{\mathrm{f}}$ : 0.65; Anal. Calcd for $\mathrm{C}_{15} \mathrm{H}_{23} \mathrm{O}_{2} \mathrm{~N}_{5}$ (15): C, 59.00; H, 7.60; N, 22.94. Found: C, 58.90; H, 7.57; N, 22.99. ${ }^{1} \mathrm{H}-\mathrm{NMR} \delta$ (ppm): 0.93 (t, $\left.J=7.29 \mathrm{~Hz}, 3 \mathrm{H}, \mathrm{CH}_{2} \mathrm{CH}_{3}\right), 1.17$ (d, $J=$ $\left.6.88 \mathrm{~Hz}, 3 \mathrm{H}, \mathrm{CH}_{3} \mathrm{CH}\right), 1.25-1.59\left(\mathrm{~m}, 4 \mathrm{H}, \mathrm{CH}_{2} \mathrm{CH}_{2} \mathrm{CH}_{3}\right.$ ), 2.05-2.13 (m, 2H, $\left.\mathrm{N}_{5} \mathrm{CH}_{2} \mathrm{CH}_{2} \mathrm{CH}_{2} \mathrm{~N}_{9}\right), 3.20-3.25(\mathrm{~m}, 2 \mathrm{H}$, $\left.\mathrm{CH}_{2} \mathrm{~N}_{9}\right), 3.35$ (s, $\left.3 \mathrm{H}, \mathrm{N}_{3} \mathrm{CH}_{3}\right), 3.50\left(\mathrm{~s}, 3 \mathrm{H}, \mathrm{N}_{1} \mathrm{CH}_{3}\right), 4.18-$ $4.24\left(\mathrm{~m}, 2 \mathrm{H}, \mathrm{N}_{5} \mathrm{CH}_{2}\right), 3.49\left(\mathrm{~s}, 3 \mathrm{H}, \mathrm{N}_{1} \mathrm{CH}_{3}\right), 4.14-4.24(\mathrm{~m}$, $\left.2 \mathrm{H}, \mathrm{N}_{5} \mathrm{CH}_{2}\right), 4.51-4.58\left(\mathrm{~m}, 1 \mathrm{H}, \mathrm{N}_{1} \mathrm{CH}=\right)$. IR $\mathrm{KBr}\left(\mathrm{cm}^{-1}\right)$ : 2,963-2,872- $\mathrm{CH}_{2}, 1,697-\mathrm{CO}(2), 1,666$ (4), 743- $\mathrm{CH}_{2}$. UV $\lambda_{\max }, \log \varepsilon: 302,4.28$.

\section{1,3-Dimethyl-9-(4-methylpentan-2-yl)-6,7,8, \\ 9-tetrahydropyrimido[2,1-f]purine-2,4(1H,3H)-dione (16)}

Reaction medium, DMF; time of heating under reflux, $5 \mathrm{~h}$; excess of amine, 2. Crystallization with ethanol $/ \mathrm{H}_{2} \mathrm{O}$ gave pure compound 16 . Yield $59 \%$, mp 116-117 ${ }^{\circ} \mathrm{C}$; TLC: $R_{\mathrm{f}}$ : 0.58; Anal. Calcd for $\mathrm{C}_{16} \mathrm{H}_{25} \mathrm{O}_{2} \mathrm{~N}_{5}$ (16): C, 60.16; H, 7.89; N, 21.93. Found: C, 60.22; H, 8.01; N, 21.96. ${ }^{1} \mathrm{H}-\mathrm{NMR} \delta(\mathrm{ppm})$ : 0.89-0.94 (m, 6H, CH( $\left.\left.\mathrm{CH}_{3}\right)_{2}\right), 1.15(\mathrm{~d}, J=6.60 \mathrm{~Hz}, 3 \mathrm{H}$, $\left.\mathrm{N}_{9} \mathrm{CHCH}_{3}\right), 1.19-1.26\left(\mathrm{~m}, 1 \mathrm{H}, \mathrm{CH}\left(\mathrm{CH}_{3}\right)_{2}\right), 1.40-1.58(\mathrm{~m}$, $\left.2 \mathrm{H}, \mathrm{CH}_{2} \mathrm{CH}\left(\mathrm{CH}_{3}\right)_{2}\right), 2.03-2.15\left(\mathrm{~m}, 2 \mathrm{H}, \mathrm{N}_{5}-\mathrm{CH}_{2}-\mathrm{CH}_{2}-\mathrm{CH}_{2}-\right.$ $\mathrm{N}_{9}$ ), 3.14-3.20 (m, 2H, $\mathrm{CH}_{2} \mathrm{~N}_{9}$ ), 3.33 (s, 3H, $\left.\mathrm{N}_{3} \mathrm{CH}_{3}\right), 3.47$ (s, 3H, $\left.\mathrm{N}_{1} \mathrm{CH}_{3}\right), 4.12-4.22\left(\mathrm{~m}, 2 \mathrm{H}, \mathrm{N}_{5} \mathrm{CH}_{2}\right), 4.57-4.67$ (m, $\left.1 \mathrm{H}, \mathrm{N}_{9} \mathrm{CHCH}_{3}\right)$. IR $\mathrm{KBr}\left(\mathrm{cm}^{-1}\right): 2,952-2,867-\mathrm{CH}_{2}, 1,699-$ $\mathrm{CO}(2), 1,660$ (4), 742- $\mathrm{CH}_{2}$. UV $\lambda_{\max }, \log \varepsilon: 301.5,4.21$.

\section{1,3-Dimethyl-9-(2-methylhexyl)-6, 7,8, \\ 9-tetrahydropyrimido[2,1-f]purine-2,4(1H,3H)-dione (17)}

Reaction medium, DMF; time of heating under reflux, $5 \mathrm{~h}$; excess of amine, 4. Crystallization with ethanol $/ \mathrm{H}_{2} \mathrm{O}$ gave pure compound 17 . Yield $81 \%, \mathrm{mp} 122-124{ }^{\circ} \mathrm{C}$; TLC: $R_{\mathrm{f}}$ : 0.63; Anal. Calcd for $\mathrm{C}_{17} \mathrm{H}_{27} \mathrm{O}_{2} \mathrm{~N}_{5}$ (17): C, 61.24; $\mathrm{H}, 8.17$; , 21.01. Found: C, 61.51; H, 8.19; N, 21.12. ${ }^{1} \mathrm{H}-\mathrm{NMR} \delta(\mathrm{ppm})$ : 0.84-0.89 (m, 6H, 2CH 3$), 1.18-1.59\left(\mathrm{~m}, 8 \mathrm{H}, \mathrm{CH}_{2} \mathrm{CH}\left(\mathrm{CH}_{2}\right)_{3}\right.$
$\left.\mathrm{CH}_{2} \mathrm{CH}_{3}\right), 1.40-1.58\left(\mathrm{~m}, 2 \mathrm{H}, \mathrm{CH}_{2} \mathrm{CH}\left(\mathrm{CH}_{3}\right)_{2}\right), 2.06-2.13(\mathrm{~m}$, $2 \mathrm{H}, \mathrm{N}_{5} \mathrm{CH}_{2} \mathrm{CH}_{2} \mathrm{CH}_{2} \mathrm{~N}_{9}$ ), 3.17-3.21 (m, 2H, $\left.\mathrm{CH}_{2} \mathrm{~N}_{9}\right), 3.36$ (s, $\left.3 \mathrm{H}, \mathrm{N}_{3} \mathrm{CH}_{3}\right), 3.48\left(\mathrm{~s}, 3 \mathrm{H}, \mathrm{N}_{1} \mathrm{CH}_{3}\right), 4.21(\mathrm{t}, J=6.05 \mathrm{~Hz}, 2 \mathrm{H}$, $\left.\mathrm{N}_{5} \mathrm{CH}_{2}\right), 4.29-4.35\left(\mathrm{~m}, 1 \mathrm{H}, \mathrm{N}_{9} \mathrm{CH}\right)$. IR $\mathrm{KBr}\left(\mathrm{cm}^{-1}\right): 2,960$ $2,861-\mathrm{CH}_{2}, 1,699-\mathrm{CO}(2), 1,659$ (4), 750- $\mathrm{CH}_{2}$. UV $\lambda_{\max }, \log \varepsilon: 302,4.31$.

9-(Heptan-2-yl)-1,3-dimethyl-6,7,8,

9-tetrahydropyrimido[2,1-f]purine-2,4(1H,3H)-dione (18)

Reaction medium, DMF; time of heating under reflux, $10 \mathrm{~h}$; excess of amine, 2. Crystallization with ethanol $/ \mathrm{H}_{2} \mathrm{O}$ gave pure compound 18. Yield $57 \%$, mp $94-96{ }^{\circ} \mathrm{C}$; Anal. Calcd for $\mathrm{C}_{17} \mathrm{H}_{27} \mathrm{O}_{2} \mathrm{~N}_{5}$ (18): C, 61.24; $\mathrm{H}, 8.17$; N, 21.01. Found: $\mathrm{C}$, 60.95; H, 7.90; N, 21.05. ${ }^{1} \mathrm{H}-\mathrm{NMR} \delta$ (ppm): 0.84-0.94 (m, 3H, $\left.\left(\mathrm{CH}_{2}\right) 4-\mathrm{CH}_{3}\right), 1.17\left(\mathrm{~d}, \mathrm{~J}=6.87 \mathrm{~Hz}, 3 \mathrm{H}, \mathrm{CHCH}_{3}\right), 1.26-1.59$ (m, 8H, $\left.\left(\mathrm{CH}_{2}\right)_{4} \mathrm{CH}_{3}\right), 2.05-2.13\left(\mathrm{~m}, 2 \mathrm{H}, \mathrm{N}_{5} \mathrm{CH}_{2} \mathrm{CH}_{2} \mathrm{CH}_{2} \mathrm{~N}_{9}\right.$ ), 3.20-3.25 (m, 2H, $\left.\mathrm{CH}_{2} \mathrm{~N}_{9}\right), 3.35\left(\mathrm{~s}, 3 \mathrm{H}, \mathrm{N}_{3} \mathrm{CH}_{3}\right), 3.49$ (s, $3 \mathrm{H}$, $\left.\mathrm{N}_{1} \mathrm{CH}_{3}\right), 4.13-4.24\left(\mathrm{~m}, 2 \mathrm{H}, \mathrm{N}_{5} \mathrm{CH}_{2}\right), 4.50-4.56(\mathrm{~m}, 1 \mathrm{H}$, $\left.\mathrm{N}_{9} \mathrm{CH}\right)$. IR $\mathrm{KBr}\left(\mathrm{cm}^{-1}\right): 2,955-2,859-\mathrm{CH}_{2}, 1,701-\mathrm{CO}(2)$, 1,656 (4), 745- $-\mathrm{CH}_{2}$. UV $\lambda_{\max }, \log \varepsilon: 302,4.30$.

\section{1,3-Dimethyl-9-(6-methylheptan-2-yl)-6,7,8,}

9-tetrahydropyrimido[2,1-f]purine-2,4(1H,3H)-dione (19)

Reaction medium, DMF; time of heating under reflux, $5 \mathrm{~h}$; excess of amine, 2. Crystallization with ethanol/ $\mathrm{H}_{2} \mathrm{O}$ gave pure compound 19. Yield $60 \%$ mp $99-101{ }^{\circ} \mathrm{C}$; TLC: $R_{\text {f: }} 0.48$; Anal. Calcd for $\mathrm{C}_{18} \mathrm{H}_{29} \mathrm{O}_{2} \mathrm{~N}_{5}$ (19): C, 61.24; H, 8.17; N, 21.01. Found: C, 61.99; H, 8.21; N, 20.19. ${ }^{1} \mathrm{H}-\mathrm{NMR} \delta$ (ppm): 0.83 $0.86\left(\mathrm{~m}, 6 \mathrm{H}, \mathrm{CH}\left(\mathrm{CH}_{3}\right)_{2}\right), 1.18\left(\mathrm{~d}, J=6.87 \mathrm{~Hz}, 3 \mathrm{H}, \mathrm{N}_{9} \mathrm{CHCH}_{3}\right)$, $1.23-1.38\left(\mathrm{~m} 1 \mathrm{H} \mathrm{CH}\left(\mathrm{CH}_{3}\right)_{2}\right), 1.43-1.61\left(\mathrm{~m}, 6 \mathrm{H},\left(\mathrm{CH}_{2}\right)_{3}\right)$, 2.06-2.14 (m, 2H, $\left.\mathrm{CH}_{2} \mathrm{~N}_{9}\right), 3.36\left(\mathrm{~s}, 3 \mathrm{H}, \mathrm{N}_{3} \mathrm{CH}_{3}\right), 3.50$ (s, 3H, $\left.\mathrm{N}_{1} \mathrm{CH}_{3}\right), 4.12-4.27\left(\mathrm{~m}, 2 \mathrm{H}, \mathrm{N}_{5} \mathrm{CH}_{2}\right), 4.46-4.58(\mathrm{~m}$, $\left.1 \mathrm{H}, \mathrm{N}_{9} \mathrm{CHCH}_{3}\right)$. IR KBr $\left(\mathrm{cm}^{-1}\right): 2,956-2,858-\mathrm{CH}_{2}, 1,708-$ $\mathrm{CO}(2), 1,651$ (4), 742- $\mathrm{CH}_{2}$. UV $\lambda_{\max }, \log \varepsilon: 302.5,4.25$.

9-Allyl-1,3-dimethyl-6, 7,8,9-tetrahydropyrimido[2,1-f] purine-2,4(1H,3H)-dione (23)

Reaction medium, solvent-free; time of heating under reflux, $5 \mathrm{~h}$; excess of amine, 20. Crystallization with ethanol (10\%) gave pure compound 23. Yield $65 \%$, mp $157-159{ }^{\circ} \mathrm{C}$; TLC: $R_{\mathrm{f}}$ : 0.35; Anal. Calcd for $\mathrm{C}_{13} \mathrm{H}_{17} \mathrm{O}_{2} \mathrm{~N}_{5}(\mathbf{2 3})$ : C, 56.71; H, 6.22; N, 24.44. Found: C, 56.88; H, 6.48; N, 25.12. ${ }^{1} \mathrm{H}-\mathrm{NMR} \delta(\mathrm{ppm}): 2.10-2.18(\mathrm{~m}, 2 \mathrm{H}$, $\left.\mathrm{N}_{5} \mathrm{CH}_{2} \mathrm{CH}_{2} \mathrm{CH}_{2} \mathrm{~N}_{9}\right), 3.29\left(\mathrm{t}, J=5.65 \mathrm{~Hz}, 2 \mathrm{H}, \mathrm{CH}_{2} \mathrm{~N}_{9}\right.$ ), $3.34\left(\mathrm{~s}, 3 \mathrm{H}, \mathrm{N}_{3} \mathrm{CH}_{3}\right), 3.48\left(\mathrm{~s}, 3 \mathrm{H}, \mathrm{N}_{1} \mathrm{CH}_{3}\right), 4.16(\mathrm{t}, J=$ $\left.6.04 \mathrm{~Hz}, 2 \mathrm{H}, \mathrm{N}_{9} \mathrm{CH}_{2}\right), 4.20\left(\mathrm{t}, J=6.04 \mathrm{~Hz}, 2 \mathrm{H}, \mathrm{N}_{5} \mathrm{CH}_{2}\right)$, $5.20-5.26\left(\mathrm{~m}, 2 \mathrm{H}, \mathrm{CH}_{2}=\mathrm{CH}\right), 5.75-5.88\left(\mathrm{~m}, 1 \mathrm{H}, \mathrm{CH}_{2}=\right.$ $\mathrm{CH})$. IR $\mathrm{KBr}\left(\mathrm{cm}^{-1}\right)$ : 3,081- $\mathrm{CH}_{2}-\mathrm{CH}=\mathrm{CH}_{2}, 2,944-$ 2,902 $\mathrm{CH}_{2}, 1,695-\mathrm{CO}(2), 1,664$ (4), 750- $\mathrm{CH}_{2}$. UV $\lambda_{\max }, \log \varepsilon: 303.5,4.30$. 
1,3-Dimethyl-9-(prop-2-ynyl)-6,7,8,

9-tetrahydropyrimido[2,1-f]purine-2,4(1H,3H)-dione (24)

Reaction medium, n-butanol; time of heating under reflux, $10 \mathrm{~h}$; excess of amine, 5. Crystallization with ethanol (30\%) gave pure compound 24 . Yield $93 \%$, mp 203-206 ${ }^{\circ} \mathrm{C}$; TLC: $R_{\mathrm{f}}$ : 0.57; Anal. Calcd for $\mathrm{C}_{13} \mathrm{H}_{15} \mathrm{O}_{2} \mathrm{~N}_{5}$ (24): C, 57.14; $\mathrm{H}$, 5.54; N, 25.62. Found: C, 57.44; H, 5.66; N, 25.79. ${ }^{1} \mathrm{H}-$ NMR $\delta$ (ppm): $2.18-2.29$ (m, 3H, $\left.\mathrm{N}_{5} \mathrm{CH}_{2} \mathrm{CH}_{2} \mathrm{CH}_{2}+\mathrm{CH} \equiv\right)$, 3.35 (s, $\left.3 \mathrm{H}, \mathrm{N}_{3} \mathrm{CH}_{3}\right), 3.35-3.42\left(\mathrm{~m}, 2 \mathrm{H}, \mathrm{CH}_{2} \mathrm{~N}_{9}\right), 3.50$ (s, $\left.3 \mathrm{H}, \mathrm{N}_{1} \mathrm{CH}_{3}\right), 4.36\left(\mathrm{t}, J=6.05 \mathrm{~Hz}, 2 \mathrm{H}, \mathrm{N}_{9} \mathrm{CH}_{2}\right)$. IR $\mathrm{KBr}$ $\left(\mathrm{cm}^{-1}\right): 3,123-\mathrm{CH}_{2}-\mathrm{CH}=\mathrm{CH}_{2}, 2,952-\mathrm{CH}_{2}, 1,701-\mathrm{CO}$ (2), 1,665 (4), 744- $-\mathrm{CH}_{2}$. UV $\lambda_{\max }, \log \varepsilon: 296,4.19$.

Synthesis of 9-ethenyl 1,3-dimethyl-6,7,8, 9-tetrahydropyrimido[2,1-f]purine-2,4(1H,3H)-dione (22)

A mixture of 9-(2-bromoethyl)-1,3-dimethyl-6,7,8,9tetrahydropyrimido[2,1-f]purine-2,4 $(1 H, 3 H)$-dione $(0.68 \mathrm{~g}$, $2 \mathrm{mmol})$ (21) [27] and $\mathrm{KOH}(0.11 \mathrm{~g}, 2 \mathrm{mmol})$ in $10 \mathrm{ml}$ ethanol was heated at reflux for $20 \mathrm{~h}$. After cooling, the precipitate was separated and washed with water and crystallized from methoxyethanol. Yield $70 \%$, mp $268-271{ }^{\circ} \mathrm{C}$; TLC: $R_{\mathrm{f}}$ : 0.55 ; Anal. Calcd for $\mathrm{C}_{12} \mathrm{H}_{15} \mathrm{O}_{2} \mathrm{~N}_{5}$ (22): C, 55.19; H, 5.79; N, 26.80 . Found: C, 55.47; H, 5.55; N, 26.45. ${ }^{1} \mathrm{H}-\mathrm{NMR} \delta$ (ppm): 2.17 $2.28\left(\mathrm{~m}, 2 \mathrm{H}, \mathrm{N}_{5} \mathrm{CH}_{2} \mathrm{CH}_{2} \mathrm{CH}_{2} \mathrm{~N}_{9}\right), 3.38\left(\mathrm{~s}, 3 \mathrm{H}, \mathrm{N}_{3} \mathrm{CH}_{3}\right), 3.53$ (s, $\left.3 \mathrm{H}, \mathrm{N}_{1} \mathrm{CH}_{3}\right), 3.54-3.59\left(\mathrm{~m}, 2 \mathrm{H}, \mathrm{N}_{9} \mathrm{CH}_{2}\right), 4.26-4.52(\mathrm{~m}, 4 \mathrm{H}$, $\left.\mathrm{N}_{5} \mathrm{CH}_{2}+\mathrm{CH}_{2}=\right), 7.38-7.48(\mathrm{~m}, 1 \mathrm{H}, \mathrm{CH}=) . \mathrm{IR} \mathrm{KBr}\left(\mathrm{cm}^{-1}\right)$ : $3,108-3,089-\mathrm{CH}=\mathrm{CH}_{2}, 2,983-2883 \mathrm{CH}_{2}, 1,701-\mathrm{CO}$ (2), 1,652 (4), $746-\mathrm{CH}_{2}$. UV $\lambda_{\max }, \log \varepsilon: 304,4.40$.

General procedure for the synthesis of 10-substituted 1,3-dimethyl-6,7,8,9-tetrahydrodiazepino[2,1-f]purine2,4(1H,3H)-diones (26-32)

A mixture of 7-(4-bromobutyl)-8-bromotheophylline (0.79 g, 2 mmol) (3) [23] and an amine derivative (4$72 \mathrm{mmol}$ ) was heated under reflux without solvent or with ethanol, isobutanol or DMF for 5-10 h. Compounds 30 and 31 precipitated by adding water to the reaction mixture; compounds 26 and 27 were obtained by removing the solvent and excess of amine by distillation under reduced pressure and adding water to the residue. Compounds 28, 29 and 32 precipitated by removing the excess of amine by steam distillation and cooling the water solution. All compounds were purified by crystallization from diluted ethanol or by dissolving in ethanol and precipitation with water.

\section{0-Ethyl-1,3-dimethyl-6, 7,8,9-tetrahydrodiazepino[2,1-f] purine-2,4(1H,3H)-dione (26)}

Reaction medium, ethanol; time of heating under reflux, $10 \mathrm{~h}$; excess of amine, 36. Crystallization with ethanol
(30\%) gave pure compound 26. Yield $38 \%$, mp 124$125^{\circ} \mathrm{C}$; TLC: $R_{\mathrm{f}}$ : 0.62; Anal. Calcd for $\mathrm{C}_{13} \mathrm{H}_{19} \mathrm{O}_{2} \mathrm{~N}_{5}$ (26): C, 56.29; H, 6.91; N, 25.24. Found: C, 56.08; H, 6.64; N, 25.50. ${ }^{1} \mathrm{H}-\mathrm{NMR} \delta(\mathrm{ppm}): 1.22-1.26(\mathrm{t}, J=7.01 \mathrm{~Hz}, 3 \mathrm{H}$, $\left.\mathrm{CH}_{3} \mathrm{CH}_{2}\right), 1.27-1.92\left(\mathrm{~s}, 4 \mathrm{H}, \mathrm{N}_{5} \mathrm{CH}_{2}\left(\mathrm{CH}_{2}\right)_{2} \mathrm{CH}_{2}\right), 3.30$ $3.23\left(\mathrm{~m}, 2 \mathrm{H}, \mathrm{CH}_{2} \mathrm{CH}_{3}\right), 3.37$ (s, $\left.3 \mathrm{H}, \mathrm{N}_{3} \mathrm{CH}_{3}\right), 3.51$ (s, $3 \mathrm{H}$, $\left.\mathrm{N}_{1} \mathrm{CH}_{3}\right), 3.54-3.56\left(\mathrm{~m}, 2 \mathrm{H}, \mathrm{CH}_{2} \mathrm{~N}_{10}\right), 4.28-4.31(\mathrm{~m}, 2 \mathrm{H}$, $\left.\mathrm{N}_{5} \mathrm{CH}_{2}\right)$. IR $\mathrm{KBr}\left(\mathrm{cm}^{-1}\right): 2,952-2873-\mathrm{CH}_{2}, 1,693-$ $\mathrm{CO}(2), 1,661$ (4), $740-\mathrm{CH}_{2}$. UV $\lambda_{\max }, \log \varepsilon: 300,4.22$.

\section{1,3-Dimethyl-10-propyl-6, 7,8,9-tetrahydrodiazepino[2,1-f]} purine-2,4(1H,3H)-dione (27)

Reaction medium, isobutanol; time of heating under reflux, $10 \mathrm{~h}$; excess of amine, 11. Crystallization with ethanol (30\%) gave pure compound 27 . Yield $46 \%$, mp 153$154{ }^{\circ} \mathrm{C}$; TLC: $R_{\mathrm{f}}$ : 0.64; Anal. Calcd for $\mathrm{C}_{14} \mathrm{H}_{21} \mathrm{O}_{2} \mathrm{~N}_{5}$ (27): C, 57.71; H, 7.27; N, 24.03. Found: C, 57.76; H, 6.98; N, 23.66. ${ }^{1} \mathrm{H}-\mathrm{NMR} \delta(\mathrm{ppm}): 0.91(\mathrm{t}, J=7.43 \mathrm{~Hz}, 3 \mathrm{H}$, $\left.\left(\mathrm{CH}_{2}\right)_{2} \mathrm{CH}_{3}\right), 1.57-1.73\left(\mathrm{~m}, 2 \mathrm{H}, \mathrm{CH}_{2} \mathrm{CH}_{2} \mathrm{CH}_{3}\right), 1.87-1.91$ (m, 4H, $\left.\mathrm{N}_{5} \mathrm{CH}_{2}\left(\mathrm{CH}_{2}\right)_{2} \mathrm{CH}_{2} \mathrm{~N}_{10}\right), 3.24(\mathrm{t}, J=5.45 \mathrm{~Hz}, 2 \mathrm{H}$, $\mathrm{CH}_{2} \mathrm{CH}_{2} \mathrm{CH}_{3}$ ), 3.37 (s, $2 \mathrm{H}, \mathrm{N}_{3} \mathrm{CH}_{3}$ ), 3.42-3.47 (s, $2 \mathrm{H}$, $\mathrm{CH}_{2} \mathrm{~N}_{10}$ ), 3.51 (s, $\left.3 \mathrm{H}, \mathrm{N}_{1} \mathrm{CH}_{3}\right), 4.31$ (t, $J=5.08 \mathrm{~Hz}, 2 \mathrm{H}$, $\left.\mathrm{N}_{5} \mathrm{CH}_{2}\right)$. IR $\mathrm{KBr}\left(\mathrm{cm}^{-1}\right)$ : 2,935-2870- $\mathrm{CH}_{2}, 1,692-$ $\mathrm{CO}(2), 1,653$ (4), $750-\mathrm{CH}_{2}$. UV $\lambda_{\max }, \log \varepsilon: 300,4.30$.

10-Butyl-1,3-dimethyl-6, 7,8,9-tetrahydrodiazepino[2,1-f] purine-2,4(1H,3H)-dione (28)

Reaction medium, solvent-free; time of heating under reflux, $5 \mathrm{~h}$; excess of amine, 25. Crystallization with ethanol/ $\mathrm{H}_{2} \mathrm{O}$ gave pure compound 28 . Yield $72 \%$, mp 84 $86{ }^{\circ} \mathrm{C}$; TLC: $R_{\mathrm{f}}$ : 0.70; Anal. Calcd for $\mathrm{C}_{15} \mathrm{H}_{23} \mathrm{O}_{2} \mathrm{~N}_{5}(\mathbf{2 8})$ : C, 58.99; H, 7.60; N, 22.93. Found: C, 58.89; H, 7.22; N, 22.60. ${ }^{1} \mathrm{H}-\mathrm{NMR} \delta(\mathrm{ppm}): 0.95(\mathrm{t}, J=7.28 \mathrm{~Hz}, 3 \mathrm{H}$, $\left.\left(\mathrm{CH}_{2}\right)_{3} \mathrm{CH}_{3}\right), 1.30-1.42\left(\mathrm{~m}, 2 \mathrm{H}, \mathrm{CH}_{2} \mathrm{CH}_{2} \mathrm{CH}_{2} \mathrm{CH}_{3}\right), 1.57-$ $1.67\left(\mathrm{~m}, 2 \mathrm{H}, \mathrm{CH}_{3} \mathrm{CH}_{2} \mathrm{CH}_{2} \mathrm{CH}_{3}\right), 1.87-1.88(\mathrm{~m}, 4 \mathrm{H}$ $\left.\mathrm{N}_{5} \mathrm{CH}_{2}\left(\mathrm{CH}_{2}\right)_{2} \mathrm{CH}_{2} \mathrm{~N}_{10}\right), 3.23$ (t, $J=5.01 \mathrm{~Hz}, 2 \mathrm{H} \mathrm{N}_{10} \mathrm{CH}_{2}$ ), 3.37 (s, $3 \mathrm{H}, \mathrm{N}_{3} \mathrm{CH}_{3}$ ), 3.48 (t, J=7.48 Hz, $2 \mathrm{H}, \mathrm{CH}_{2} \mathrm{~N}_{10}$ ), 3.51 (s, $3 \mathrm{H}, \mathrm{N}_{1} \mathrm{CH}_{3}$ ), 4.30 (t, $J=5.09 \mathrm{~Hz}, 2 \mathrm{H}, \mathrm{N}_{5} \mathrm{CH}_{2}$ ). IR $\mathrm{KBr}$ $\left(\mathrm{cm}^{-1}\right): 2,957-2,871-\mathrm{CH}_{2}, 1,700-\mathrm{CO}(2), 1,658$ (4), $745-\mathrm{CH}_{2}$. UV $\lambda_{\max }, \log \varepsilon: 300,4.28$.

10-Sec-butyl-1,3-dimethyl-6, 7,8,9-tetrahydrodiazepino [2,1-f]purine-2,4(1H,3H)-dione) (29)

Reaction medium, solvent-free; time of heating under reflux, $10 \mathrm{~h}$; excess of amine, 10. Crystallization with ethanol (50\%) gave pure compound 29. Yield $57 \%$, mp $138-140{ }^{\circ} \mathrm{C}$; TLC: $R_{\mathrm{f}}$ : 0.53; Anal. Calcd for $\mathrm{C}_{15} \mathrm{H}_{23} \mathrm{O}_{2} \mathrm{~N}_{5}$ (29): C, 58.99; H, 7.60; N, 22.93. Found: C, 58.67; H, 7.30; N, 22.75. ${ }^{1} \mathrm{H}-\mathrm{NMR} \delta(\mathrm{ppm}): 0.95(\mathrm{t}, J=1.10 \mathrm{~Hz}, 3 \mathrm{H}$, $\mathrm{CH}_{2} \mathrm{CH}_{3}$ ), 1.22 (d, $\left.J=7.60 \mathrm{~Hz}, 3 \mathrm{H}, \mathrm{CHCH}_{3}\right), 1.45-1.72$ 
$\left(\mathrm{m}, \quad 2 \mathrm{H}, \quad \mathrm{CH}_{3} \mathrm{CH}_{2}\right), \quad 1.72-2.00(\mathrm{~m}, \quad 4 \mathrm{H}$, $\left.\mathrm{N}_{5} \mathrm{CH}_{2}\left(\mathrm{CH}_{2}\right)_{2} \mathrm{CH}_{2} \mathrm{~N}_{10}\right), 2.98-3.28\left(\mathrm{~m}, 2 \mathrm{H}, \mathrm{CH}_{2} \mathrm{~N}_{10}\right), 3.37$ (s, $\left.2 \mathrm{H}, \mathrm{N}_{3} \mathrm{CH}_{3}\right), 3.48\left(\mathrm{t}, J=7.48 \mathrm{~Hz}, 2 \mathrm{H}, \mathrm{CH}_{2} \mathrm{~N}_{10}\right), 3.51$ (s, $3 \mathrm{H}$, $\left.\mathrm{N}_{1} \mathrm{CH}_{3}\right), 4.01-4.12\left(\mathrm{~m}, 2 \mathrm{H}, \mathrm{N}_{5} \mathrm{CH}_{2}\right), 4.51-4.58(\mathrm{~m}, 1 \mathrm{H}$, $\left.\mathrm{CHCH}_{3}\right)$. IR $\mathrm{KBr}\left(\mathrm{cm}^{-1}\right): 2,966-2,876-\mathrm{CH}_{2}, 1,701-$ $\mathrm{CO}(2), 1,660$ (4), 745- $\mathrm{CH}_{2}$. UV $\lambda_{\max }, \log \varepsilon: 300,4.20$.

\section{1,3-Dimethyl-10-(4-methylpentan-2-yl)-6,7,8,}

9-tetrahydrodiazepino[2,1-f]purine-2,4(1H,3H)-dione (30)

Reaction medium, DMF; time of heating under reflux, $10 \mathrm{~h}$; excess of amine, 2. Crystallization with ethanol $/ \mathrm{H}_{2} \mathrm{O}$ gave pure compound 30 . Yield $61 \%$, mp $96-100{ }^{\circ} \mathrm{C}$; TLC: $R_{\mathrm{f}}$ : 0.72; Anal. Calcd for $\mathrm{C}_{17} \mathrm{H}_{27} \mathrm{O}_{2} \mathrm{~N}_{5}(\mathbf{3 0})$ : C, 61.22; H, 8.17; N, 21.02. Found: C, $61.52 ; \mathrm{H}, 8.09 ; \mathrm{N}, 20.90 .{ }^{1} \mathrm{H}-\mathrm{NMR} \delta(\mathrm{ppm})$ : 0.92-0.94 (m, 6H, CH(CH $\left.)_{2}\right), 1.19-1.28$ (m, 4H CHCH ${ }_{3}+$ $\left.\mathrm{CH}\left(\mathrm{CH}_{3}\right)_{2}\right), 1.50-1.67\left(\mathrm{~m}, 2 \mathrm{H}, \mathrm{CH}_{2} \mathrm{CH}\right), 1.73-1.97$ (m, 4H, $\left.\mathrm{N}_{5} \mathrm{CH}_{2}\left(\mathrm{CH}_{2}\right)_{2} \mathrm{CH}_{2} \mathrm{~N}_{10}\right), 2.99-3.27\left(\mathrm{~m}, 2 \mathrm{H}, \mathrm{CH}_{2} \mathrm{~N}_{10}\right), 3.36$ (s, $\left.3 \mathrm{H}, \mathrm{N}_{3} \mathrm{CH}_{3}\right), 3.50\left(\mathrm{~s}, 3 \mathrm{H}, \mathrm{N}_{1} \mathrm{CH}_{3}\right), 4.02-4.10(\mathrm{~m}, 1 \mathrm{H}$, $\left.\mathrm{N}_{5} \mathrm{CH}\right), 4.27-4.34\left(\mathrm{~m}, 2 \mathrm{H}, \mathrm{N}_{5} \mathrm{CH}_{2}\right), 4.48-4.55(\mathrm{~m}, 1 \mathrm{H}$, $\left.\mathrm{N}_{10} \mathrm{CH}\right)$. IR $\mathrm{KBr}\left(\mathrm{cm}^{-1}\right): 2,946-2,876-\mathrm{CH}_{2}, 1,695-$ $\mathrm{CO}(2), 1,664$ (4), $747-\mathrm{CH}_{2}$. UV $\lambda_{\max }, \log \varepsilon: 300,4.37$.

\section{1,3-Dimethyl-10-(pentan-2-yl)-6,7,8,}

9-tetrahydrodiazepino[2,1-f]purine-2,4(1H,3H)-dione (31)

Reaction medium, DMF; time of heating under reflux, $10 \mathrm{~h}$; excess of amine, 2. Crystallization with ethanol $/ \mathrm{H}_{2} \mathrm{O}$ gave pure compound 31 . Yield $78 \%, \mathrm{mp} 113-115{ }^{\circ} \mathrm{C}$; TLC: $R_{\mathrm{f}}$ : 0.70; Anal. Calcd for $\mathrm{C}_{16} \mathrm{H}_{25} \mathrm{O}_{2} \mathrm{~N}_{5}$ (31): C, 60.17; H, 7.90; $\mathrm{N}, 21.93$. Found: C, 60.19; H, 7.85; N, 21.78. ${ }^{1} \mathrm{H}-\mathrm{NMR} \delta$ (ppm): $0.90-0.94\left(\mathrm{~m}, 3 \mathrm{H}, \mathrm{CH}_{2} \mathrm{CH}_{3}\right), 1.21$ (d, $J=6.88 \mathrm{~Hz}$, $\left.3 \mathrm{H}, \mathrm{CHCH}_{3}\right), 1.32-1.64\left(\mathrm{~m}, 4 \mathrm{H},\left(\mathrm{CH}_{2}\right)_{2} \mathrm{CH}_{3}\right), 1.74-1.98$ $\left(\mathrm{m}, 4 \mathrm{H}, \mathrm{N}_{5} \mathrm{CH}_{2}\left(\mathrm{CH}_{2}\right)_{2} \mathrm{CH}_{2} \mathrm{~N}_{10}\right), 2.99-3.07(\mathrm{~m}, 1 \mathrm{H}$, $\left.\mathrm{CH}_{2} \mathrm{~N}_{10}\right), 3.20-3.28\left(\mathrm{~m}, 1 \mathrm{H}, \mathrm{CH}_{2} \mathrm{~N}_{10}\right), 3.50(\mathrm{~s}, 3 \mathrm{H}$, $\left.\mathrm{N}_{1} \mathrm{CH}_{3}\right), 4.01-4.09\left(\mathrm{~m}, 1 \mathrm{H}, \mathrm{N}_{5} \mathrm{CH}\right), 4.17-4.24(\mathrm{~m}, 2 \mathrm{H}$, $\left.\mathrm{N}_{5} \mathrm{CH}_{2}\right), 4.49-4.57\left(\mathrm{~m}, 1 \mathrm{H}, \mathrm{N}_{10} \mathrm{CH}\right)$. IR $\mathrm{KBr}\left(\mathrm{cm}^{-1}\right)$ : 2,949-2,871- $\mathrm{CH}_{2}, 1,700-\mathrm{CO}(2), 1,661$ (4), 745- $\mathrm{CH}_{2}$. UV $\lambda_{\max }, \log \varepsilon: 300,4.29$.

\section{0-Allyl-1,3-dimethyl-6, 7,8,9-tetrahydrodiazepino[2,1-f] purine-2,4(1H,3H)-dione (32)}

Reaction medium, solvent-free; time of heating under reflux, $5 \mathrm{~h}$; excess of amine, 20. Crystallization with ethanol $/ \mathrm{H}_{2} \mathrm{O}$ gave pure compound 32. Yield $65 \%$, mp 228-230 ${ }^{\circ} \mathrm{C}$; TLC: $R_{\mathrm{f}}$ : 0.62; Anal. Calcd for $\mathrm{C}_{17} \mathrm{H}_{25} \mathrm{O}_{2} \mathrm{~N}_{5}$ (32): C, 58.11; H, 6.63; N, 24.20. Found: C, 58.23; H, 6.48; $\mathrm{N}, 24.36 .{ }^{1} \mathrm{H}-\mathrm{NMR} \delta(\mathrm{ppm}): 1.83-1.90(\mathrm{~m}, 4 \mathrm{H}$, $\left.\mathrm{N}_{5} \mathrm{CH}_{2}\left(\mathrm{CH}_{2}\right)_{2} \mathrm{CH}_{2} \mathrm{~N}_{10}\right), 3.15$ (t, $J=4.95 \mathrm{~Hz}, 2 \mathrm{H}, \mathrm{CH}_{2} \mathrm{~N}_{10}$ ), $3.37\left(\mathrm{~s}, 3 \mathrm{H}, \mathrm{N}_{3} \mathrm{CH}_{3}\right), 3.51\left(\mathrm{~s}, 3 \mathrm{H}, \mathrm{N}_{1} \mathrm{CH}_{3}\right), 4.07$ (d, $J=$ $4.95 \mathrm{~Hz}, 2 \mathrm{H}, \mathrm{N}_{10} \mathrm{CH}_{2}$ ), 4.33 (t, $J=4.95 \mathrm{~Hz}, 2 \mathrm{H}, \mathrm{N}_{5} \mathrm{CH}_{2}$ ), 5.21-5.30 (m, 2H, $\left.\mathrm{CH}_{2}=\mathrm{CH}\right), 5.89-6.00\left(\mathrm{~m}, 1 \mathrm{H}, \mathrm{CH}_{2}=\mathrm{CH}\right)$.
IR $\mathrm{KBr}\left(\mathrm{cm}^{-1}\right): 3,078-3,010$-allyl, 2,936- $\mathrm{CH}_{2}, 1,696-$ $\mathrm{CO}(2), 1,652$ (4), $750-\mathrm{CH}_{2}$. UV $\lambda_{\max }, \log \varepsilon: 298,4.23$.

8-Isopropyl-1,3-dimethyl-6,7-dihydro-1H-imidazo[2,1-f] purine-2,4(1H,3H)-dione (34)

A mixture of $(0.73 \mathrm{~g}, 2 \mathrm{mmol})$ of 7-(2-bromoethyl)-8bromotheophylline (1) $[16,21]$ and isopropyl amine $(1.42 \mathrm{~g}$, $24 \mathrm{mmol}$ ) was heated under reflux for $5 \mathrm{~h}$. After cooling, the precipitate was separated and crystallized from $30 \%$ ethanol to give analytically pure compound $\mathbf{3 4}$. Yield $50 \%$, mp $157-$ $159^{\circ} \mathrm{C}$; Anal. Calcd for $\mathrm{C}_{12} \mathrm{H}_{17} \mathrm{O}_{2} \mathrm{~N}_{5}$ (34): C, 54.74; $\mathrm{H}, 6.50$; N, 26.60. Found: C, 54.35; H, 6.50; N, 26.28. ${ }^{1} \mathrm{H}-\mathrm{NMR} \delta$ (ppm): $1.83-1.90$ (m, 4H, $\left.\mathrm{N}_{5} \mathrm{CH}_{2}\left(\mathrm{CH}_{2}\right)_{2} \mathrm{CH}_{2} \mathrm{~N}_{10}\right), 3.15$ (t, $J=$ $\left.4.95 \mathrm{~Hz}, 2 \mathrm{H}, \mathrm{CH}_{2} \mathrm{~N}_{10}\right), 3.37\left(\mathrm{~s}, 3 \mathrm{H}, \mathrm{N}_{3} \mathrm{CH}_{3}\right), 3.51(\mathrm{~s}, 3 \mathrm{H}$, $\left.\mathrm{N}_{1} \mathrm{CH}_{3}\right), 4.07\left(\mathrm{~d}, J=4.95 \mathrm{~Hz}, 2 \mathrm{H}, \mathrm{N}_{10} \mathrm{CH}_{2}\right), 4.33$ (t, $J=$ $\left.4.95 \mathrm{~Hz}, 2 \mathrm{H}, \mathrm{N}_{5} \mathrm{CH}_{2}\right), 5.21-5.30\left(\mathrm{~m}, 2 \mathrm{H}, \mathrm{CH}_{2}=\mathrm{CH}\right), 5.89$ $6.00\left(\mathrm{~m}, 1 \mathrm{H}, \mathrm{CH}_{2}=\mathrm{CH}\right)$. IR $\mathrm{KBr}\left(\mathrm{cm}^{-1}\right): 2,960-2,870$ $\mathrm{CH}_{2}, 1,696-\mathrm{CO}(2), 1,653-\mathrm{CO}(4), 749-\mathrm{CH}_{2}-\mathrm{UV} \lambda_{\max }$, $\log \varepsilon: 302,4.21$.

\section{9-Butyl-1,3-dipropyl-6, 7,8,9-tetrahydropyrimido[2,1-f] purine-2,4(1H,3H)-dione (35)}

A mixture of $(0.78 \mathrm{~g}, 2 \mathrm{mmol})$ of 1,3-dipropylo-7-(3chloropropyl)-8-bromo-purine-2,4(3H,6H)-dione (4) [16, 17] and butyl amine $(2.20 \mathrm{~g}, 30 \mathrm{mmol})$ was heated under reflux for $5 \mathrm{~h}$. After cooling, the precipitate was separated and crystallized from ethanol to give analytically pure compound 35. Yield $45 \%$, mp $77-79{ }^{\circ} \mathrm{C}$; Anal. Calcd for $\mathrm{C}_{18} \mathrm{H}_{29} \mathrm{O}_{2} \mathrm{~N}_{5} \times \mathrm{H}_{2} \mathrm{O}$ (29): C, 59.14; H, 8.42; N, 19.16 . Found: C, 58.85; H, 8.81; N, 19.10. ${ }^{1} \mathrm{H}-\mathrm{NMR} \delta$ (ppm): 0.91-0.98 (m, 8H, CH $\left.\mathrm{CH}_{2} \mathrm{CH}_{2}+\mathrm{CH}_{3}-\mathrm{CH}_{2} \mathrm{CH}_{2} \mathrm{CH}_{2}\right)$, 1.28-1.41 (m, 6H, $\left.\mathrm{CH}_{3} \mathrm{CH}_{2} \mathrm{CH}_{2} \mathrm{~N}_{1}+\mathrm{CH}_{3} \mathrm{CH}_{2} \mathrm{CH}_{2} \mathrm{CH}_{2}\right)$, $3.24\left(\mathrm{t}, J=5.64 \mathrm{~Hz}, 2 \mathrm{H}, \mathrm{N}_{9}-\mathrm{CH}_{2}\right), 3.52(\mathrm{t}, J=7.15 \mathrm{~Hz}$, $\left.2 \mathrm{H}, \mathrm{N}_{9}-\mathrm{CH}_{2}\right), 3.89-3.98\left(\mathrm{~m}, 4 \mathrm{H}, \mathrm{N}_{1}, \mathrm{~N}_{3} \mathrm{CH}_{2} \mathrm{CH}_{2} \mathrm{CH}_{3}\right)$, $4.20\left(\mathrm{t}, J=5.19 \mathrm{~Hz}, 2 \mathrm{H}, \mathrm{N}_{5} \mathrm{CH}_{2}\right) . \quad \mathrm{IR} \mathrm{KBr}\left(\mathrm{cm}^{-1}\right)$ : 3,518-2,870 $\mathrm{H}_{2} \mathrm{O}, 2,959-2,874-\mathrm{CH}_{2}-, 1,689-\mathrm{CO}(2)$, 1,655-CO (4), 754- $\mathrm{CH}_{2}-$. UV $\lambda_{\max }, \log \varepsilon: 303,4.30$.

Pharmacology

Adenosine receptor binding studies

$\left[{ }^{3} \mathrm{H}\right] \mathrm{CCPA}(58 \mathrm{Ci} / \mathrm{mmol})$ was purchased from NEN Life Sciences; $\left[{ }^{3} \mathrm{H}\right] \mathrm{MSX}-2(84 \mathrm{Ci} / \mathrm{mmol}),\left[{ }^{3} \mathrm{H}\right] \mathrm{PSB}-11$ $(28 \mathrm{Ci} / \mathrm{mmol})$ and $\left[{ }^{3} \mathrm{H}\right] \mathrm{PSB}-603(73 \mathrm{Ci} / \mathrm{mmol})$ were obtained from Quotient Biosciences (custom synthesis). The non-radioactive precursors of $\left[{ }^{3} \mathrm{H}\right] \mathrm{MSX}-2$ (MSX-1) $[33,48],\left[{ }^{3} \mathrm{H}\right] \mathrm{PSB}-11$ (PSB-10) $[36,49]$ and $\left[{ }^{3} \mathrm{H}\right] \mathrm{PSB}-603$ (PSB-603) [35] were synthesized in our laboratory. Frozen rat brains obtained from Pel Freez ${ }^{\mathbb{R}}$, Rogers, AR, USA, were dissected to obtain cortical membrane preparations 
for $\mathrm{A}_{1}$ assays and striatal membrane preparations for $\mathrm{A}_{2 \mathrm{~A}}$ assays as described [50]. CHO cells stably transfected with the human adenosine $A_{1}, A_{2 B}$ and $A_{3}$ receptors were used for membrane preparations as previously described [50, 51]. For $\mathrm{A}_{2 \mathrm{~A}}$ adenosine receptor assays, commercially available membrane preparations containing the human $\mathrm{A}_{2 \mathrm{~A}} \mathrm{AR}$ were obtained from Perkin Elmer Life Sciences (Boston, MA, USA). Stock solutions of the compounds were prepared in dimethylsulfoxide (DMSO); the final concentration of DMSO in the assays did not exceed $2.5 \%$. Initial screening was performed at a single concentration of 25 or $10 \mu \mathrm{M}$, depending on target receptor. Binding assays were performed as previously described [33, 50-54]. Curves were determined using six to seven different concentrations of test compounds spanning three orders of magnitude. At least three separate experiments were performed, each in triplicate. For non-linear regression analysis, the Cheng-Prusoff equation and $\mathrm{KD}$ values of $0.2 \mathrm{nM}\left(\right.$ rat $\mathrm{A}_{1}$ ) and $0.6 \mathrm{nM}$ (human $\mathrm{A}_{1}$ ), respectively, for $\left[{ }^{3} \mathrm{H}\right] \mathrm{CCPA}$ [34]; $8 \mathrm{nM}$ (rat $\mathrm{A}_{2 \mathrm{~A}}$ ) and $7 \mathrm{nM}$ (human $\mathrm{A}_{2 \mathrm{~A}}$ ), respectively, for $\left[{ }^{3} \mathrm{H}\right] \mathrm{MSX}-2$ $[33,55] ; 0.41 \mathrm{nM}$ (human $\mathrm{A}_{2 \mathrm{~B}}$ ) for $\left[{ }^{3} \mathrm{H}\right] \mathrm{PSB}-603$ (human $\mathrm{A}_{2 \mathrm{~B}}$ ) [35] and $4.9 \mathrm{nM}$ (human $\mathrm{A}_{3}$ ) for [ ${ }^{3} \mathrm{H}$ ]PSB-11 [52] were used to calculate $K_{\mathrm{i}}$ values from $\mathrm{IC}_{50}$ values.

\section{Anticonvulsant screening}

The anticonvulsant evaluation was carried but using reported procedures [39, 40, 47]. Male albino mice (Carworth Farms $\mathrm{Nr} 1,18-25 \mathrm{~g}$ ) and male albino rats (Spraque-Dawley, 100-150 g) were used as experimental animals. A group of three to five mice was used in MES and ScMet tests, and a group of four to eight animals was used in rotorod tests. For the evaluation of activity after oral administration, a group of four rats was used. The test compounds were suspended in $0.5 \%$ methylcellulose water mixture.

In the preliminary screening, each compound was administered as an i.p. injection at three dose levels (30, 100 and $300 \mathrm{mg} / \mathrm{kg}$ ), with anticonvulsant activity and neurotoxicity assessed at 30-min and 4-h intervals after administration. For some compounds, also intervals of $15 \mathrm{~min}$ and $1 \mathrm{~h}$ were used. Anticonvulsant efficacy was measured by MES, ScMet and neurological deficit in the rotorod tests, and the data are presented in Table 4. Some selected derivatives were examined for oral activity in the MES and ScMet and neurotoxicity screen (rotorod test) 30 and $50 \mathrm{mg} / \mathrm{kg}$ doses. The results are summarized in Table 5.

The pharmacological parameters estimated in the preliminary screening were quantified for compounds $\mathbf{9}$ and $\mathbf{1 3}$ in mice (i.p.) (Table 7) and for comp. 9 also in rats (p.o.) (Table 6).

Anticonvulsant activity was expressed in terms of the median effective dose $\left(\mathrm{ED}_{50}\right) \mathrm{MES}$ and ScMet in mice and $\mathrm{ED}_{50} \mathrm{ScMet}$ in rats, and neurotoxicity was expressed as the median toxic dose $\left(\mathrm{TD}_{50}\right)$. For determination of $\mathrm{ED}_{50}$ and $\mathrm{TD}_{50}$, groups of eight mice and rats were given a range of i.p. or p.o. doses of the test drug until at least three points were established in the range of 10-90\% seizure protection or minimal observed neurotoxicity. From the plot of these data, the respective $\mathrm{ED}_{50}, \mathrm{TD}_{50}$ value $(95 \%)$ confidence intervals, slope of the regression line and the standard error of the slope were calculated by a computer program based on [38] methods described by Finney. For comp. 9, the hippocampal kindling model of focal seizures was applied (Table 6). In this procedure, the bipolar electrodes were placed surgically in the ventral hippocampus of adult male Spraque-Dawley rats. Stage five behavioural seizures are produced by using a stimulus consisting of a $50-\mathrm{Hz}, 10-\mathrm{s}$ train of $1-\mathrm{ms}$ biphasic $200-\mu \mathrm{A}$ pulses delivered every $30 \mathrm{~min}$ for $6 \mathrm{~h}$. A single dose of comp. 9 is then administered intraperitoneally, 15 min following the last stimulation. The anticonvulsant activity of $\mathbf{9}$ is assessed every $30 \mathrm{~min}$ for $2 \mathrm{~h}$, starting $15 \mathrm{~min}$ after administering the test material. After each stimulation, seizure scores and after discharge durations were recorded (Table 6).

\section{Molecular modelling}

The 3D molecule models of 5-35 and caffeine were built using Schrödinger Maestro molecular modelling environment [56] basing on presented crystal structures of chosen pyrimido- and diazepinopurinediones (10 and 30, respectively). The geometry optimization was performed using the multiple minimization method as implemented in MacroModel with MMFF force field and Truncated Newton Conjugate Gradient options and terminated when the root means square (RMS) of conjugate gradient was below $0.05 \mathrm{~kJ} \mathrm{~mol}^{-1} \AA^{-1}$. The minimization was carried out for water solvent, with distance-dependent dielectric constant as a way to treat electrostatic interactions.

The template 3REY was prepared to docking using the Protein Preparation Wizard option as a part of Schrodinger package. The ligand binding cavity was confined to a box with the crystal ligand in the center (size of the box set automatically), according to the receptor grid generation procedure. The studies of docking to the rigid receptor binding pocket were performed using Glide program, with standard precision (SP) mode.

For validation, redocking of XAC ligand was done. After initial docking, 10 poses for each ligand, with RMS deviation higher than $0.5 \AA$, were kept, and post-minimized, RMSD values between predicted and crystallographic positions of the ligand were calculated. Redocking of XAC was performed twice: (1) without any constraints and (2) with the amino hydrogen atom of the Asn253 (6.55) side chain used as a constrained H-bond donor for a carbonyl group of xanthine. 


\section{Molecular docking of $A_{2 A} A R$ antagonists}

Docking simulations of low-energy conformations for all of the synthesized compounds and caffeine were performed with SP mode to both templates with limitation used during redocking: the constrained H-bond between the side chain amino group of Asn253 (6.55) and the ligand. Five poses obtained after docking for each ligand (RMS deviation higher than $0.5 \AA$ ) were post-minimized, and final poses were kept and analysed according to the obtained docking score values.

For the graphic presentation of the selected structures with the highest docking scores, representing individual clusters of poses, PyMOL [57] software was used.

\section{References}

1. Fredholm BB, IJzerman AP, Jacobson KA, Linden J, Müller CE (2011) International Union of Basic and Clinical Pharmacology. LXXXI. Nomenclature and classification of adenosine receptorsan update. Pharmacol Rev 63:1-34

2. Müller CE, Jacobson KA (2011) Recent developments in adenosine receptor ligands and their potential as novel drugs. Biochim Biophys Acta 1808:1290-1308

3. Trincavelli ML, Daniele S, Martini C (2010) Adenosine receptors: what we know and what we are learning. Curr Top Med Chem 10:860-877

4. Yuzlenko O, Kieć-Kononowicz K (2006) Potent adenosine $A_{1}$ and $\mathrm{A}_{2 \mathrm{~A}}$ receptors antagonists: recent developments. Curr Med Chem 13:3609-3625

5. Müller CE (2002) P2-pyrimidinergic receptors and their ligands. Curr Pharm Des 8:2353-2369

6. Brunschweiger A, Müller CE (2006) P2 receptors activated by uracil nucleotides - an update. Curr Med Chem 13:289-312

7. Schenone S, Brullo C, Musumeci F, Bruno O, Botta M (2010) $A_{1}$ receptors ligands: past, present and future trends. Curr Top Med Chem 10:878-901

8. Cristalli G, Müller CE, Volpini R (2009) Recent developments in adenosine $\mathrm{A}_{2 \mathrm{~A}}$ receptor ligands. Handb Exp Pharmacol 193:59-98

9. Manera C, Saccomanni G (2010) $\mathrm{A}_{2 \mathrm{~A}}$ receptor ligands: past, present and future trends. Curr Top Med Chem 10:902-922

10. Yu L, Shen H-Y, Coelho JE, Araújo IM, Huang Q-Y, Day Y-J, Rebola N, Canas PM, Rapp EK, Ferrara J, Taylor D, Müller CE, Linden J, Cunha RA, Chen J-F (2008) Adenosine $A_{2 A}$ receptor antagonists exert motor and neuroprotective effects by distinct cellular mechanisms. Ann Neurol 63:338-346

11. Salamone JD, Betz AJ, Ishiwari K, Felsted J, Madson L, Mirante B, Clark K, Font L, Korbey S, Sager TN, Hockemeyer J, Müller CE (2008) Tremorolytic effects of adenosine $A_{2 A}$ antagonists: implications for parkinsonism. Front Biosci 13:3594-3605

12. Ishiwari K, Madson LJ, Farrar AM, Mingote SM, Valenta JP, DiGianvittorio MD, Frank LE, Correa M, Hockemeyer J, Müller CE, Salamone JD (2007) Injections of the selective adenosine $A_{2 A}$ antagonist MSX-3 into the nucleus accumbens core attenuate the locomotor suppression induced by haloperidol in rats. Behav Brain Res 178:190-199

13. Müller CE, Ferré S (2007) Blocking striatal adenosine $A_{2 A}$ receptors: a new strategy for basal ganglia disorders. Recent Pat CNS Drug Discov 2:1-21
14. Müller CE, Jacobson KA (2011) Xanthines as adenosine receptor antagonists. In: Fredholm BB (ed) Methylxanthines handbook of experimental pharmacology. Springer, Heidelberg, pp 151-199

15. Kieć-Kononowicz K, Drabczyńska A, Pękala E, Michalak B, Müller CE, Schumacher B, Karolak-Wojciechowska J, Duddeck H, Rockitt S, Wartchow R (2001) New developments in $A_{1}$ and $A_{2}$ adenosine receptor antagonists. Pure Appl Chem 73:1411-1420

16. Drabczyńska A, Müller CE, Lacher SK, Schumacher B, KarolakWojciechowska J, Nasal A, Kawczak P, Yuzlenko O, KiećKononowicz K (2006) Synthesis and biological activity of tricyclic aryloimidazo-, pyrimido-, and diazepinopurinediones. Bioorg Med Chem 14:7258-7281

17. Drabczyńska A, Müller CE, Karolak-Wojciechowska J, Schumacher B, Schiedel A, Yuzlenko O, Kieć-Kononowicz K (2007) N9-benzyl-substituted 1,3-dimethyl- and 1,3-dipropylpyrimido[2,1-f]purinediones: synthesis and structure-activity relationships at adenosine $\mathrm{A}_{1}$ and $\mathrm{A}_{2 \mathrm{~A}}$ receptors. Bioorg Med Chem 15:5003-5017

18. Drabczyńska A, Müller CE, Schiedel A, Schumacher B, KarolakWojciechowska J, Fruziński A, Zobnina W, Yuzlenko O, KiećKononowicz K (2007) Phenylethyl-substituted pyrimido[2,1-f] purinediones and related compounds: structure-activity relationships as adenosine $A_{1}$ and $A_{2 A}$ receptor ligands. Bioorg Med Chem 15:6956-6974

19. Drabczyńska A, Yuzlenko O, Köse M, Paskaleva M, Schiedel AC, Karolak-Wojciechowska J, Handzlik J, Karcz T, Kuder K, Müller CE, Kieć-Kononowicz K (2011) Synthesis and biological activity of tricyclic cycloalkylimidazo-, pyrimido- and diazepinopurinediones. Eur J Med Chem 46:3590-3607

20. Drabczyńska A, Zygmunt M, Sapa J, Filipek B, Müller CE, KiećKononowicz K (2011) Antiparkinsonian effects of novel adenosine $\mathrm{A}_{2 \mathrm{~A}}$ receptor antagonists. Arch Pharm 1:20-27

21. Cacace F, Masironi R (1956) Derivati della 8-mercapto-teofillina: sintesi di una 2',3'-tiazolidino-7,8-teofillina. Ann Chim (Roma) 46:806-812

22. Rockitt S, Wartchow R, Duddeck H, Drabczyńska A, KiećKononowicz K (2001) Modes of xanthine complexation to dirhodium tetrakis $[(R)$-a-methoxy-a-(trifluoromethyl)phenylacetate] in solution and in the solid state. Z Naturforsch 56b:319-324

23. Pawłowski M, Drabczyńska A, Gorczyca M, Malec D, Modzelewski J (1994) Synthesis and pharmacological screening of novel 10-substituted diazepino-[2,1-f]-purines. Acta Pol Pharm 51:385-391

24. Eckstein M, Łosoń W (1968) A search of new drugs in the group of xanthine derivatives. Dissert Pharm Pharmaceut 20:35-41

25. Eckstein M, Drabczyńska A (1973) A search for new drugs in the group of xanthine derivatives. XXXV. A new method of synthesis of 6,7,8,9-tetrahydropyrimido-[2,1-f]-purine-2,4-(1H,3H)-dione system. Pol J Pharmacol Pharm 25:171-173

26. Eckstein M, Drabczyńska A (1979) A new method for the anellation of 5-, 6-, and 7-membered rings containing two $\mathrm{N}$-atoms at the 7,8 position of the xanthine system. Synthesis 8:581-583

27. Pawłowski M, Drabczyńska A, Gorczyca M, Malec D, Modzelewski J (1991) Synthesis and preliminary pharmacological assessment of novel 9-substituted pyrimidino-[2,1-f]-purines. Pol J Pharmacol Pharm 43:61-70

28. Eckstein M (1962) A search for new drugs in the group of xanthine derivatives. XVI. Reactions of 7-halogenalkylderivatives of 8-bromoand 8-chloro-theophylline with amines. Dissert Pharm 14:435-441

29. Bergmann F, Dickstein S (1955) The relationship between spectral shifts and structural changes in uric acids and related compounds. J Am Chem Soc 77:691-694

30.Rybár A, Antoš K (1970) 1,3,7-Trisubstituted 8isothiocyanatomethylxanthines. Coll Czech Chem Commun $35: 1415-1419$ 
31. Jacobson KA, Balasubramanian R, Deflorian F, Gao Z-G (2012) G-protein-coupled adenosine (P1) and P2Y receptors: ligand design and receptor interactions. Purinergic Signal 8:419-436

32. Weyler S, Fülle F, Diekmann M, Schumacher B, Hinz S, Klotz KN, Müller CE E (2006) Improving potency, selectivity, and watersolubility of adenosine $A_{1}$ receptor antagonists: xanthines modified at position 3 and related pyrimido[1,2,3-cd]purinediones. ChemMedChem 1:891-902

33. Müller CE, Maurinsh J, Sauer R (2000) Binding of [ $\left.{ }^{3} \mathrm{H}\right] \mathrm{MSX}-2$ (3(3-hydroxypropyl)-7-methyl-8-(m-methoxystyryl)-1propargylxanthine) to rat striatal membranes-a new, selective antagonist radioligand for $\mathrm{A}_{2 \mathrm{~A}}$ adenosine receptors. Eur J Pharm Sci 10:259-265

34. Klotz K-N, Lohse MJ, Schwabe U, Cristalli G, Vittori S, Grifantini M (1989) 2-Chloro-N6- $\left[{ }^{3} \mathrm{H}\right]$ cyclopentyladenosine $\left(\left[{ }^{3} \mathrm{H}\right] \mathrm{CCPA}\right)-\mathrm{a}$ high affinity agonist radioligand for $\mathrm{A}_{1}$ adenosine receptors. Naunyn Schmiedeberg's Arch Pharmacol 340:679-683

35. Borrmann T, Hinz S, Bertarelli DCG, Li W, Florin NC, Scheiff AB, Müller CE (2009) 1-Alkyl-8-(piperazine-1-sulfonyl)phenylxanthines: development and characterization of adenosine $\mathrm{A}_{2 \mathrm{~B}}$ receptor antagonists and a new radioligand with subnanomolar affinity and subtype specificity. J Med Chem 52:3994-4006

36. Müller CE, Diekmann M, Thorand M, Ozola V (2002) $\left[{ }^{3} \mathrm{H}\right] 8$ Ethyl-4-methyl-2-phenyl-(8R)-4,5,7,8-tetrahydro- $1 H$-imidazo[2,1i]-purin-5-one ([ $\left.\left.{ }^{3} \mathrm{H}\right] \mathrm{PSB}-11\right)$, a novel high-affinity antagonist radioligand for human $\mathrm{A}_{3}$ adenosine receptors. Bioorg Med Chem Lett 12:501-503

37. Porter RJ, Cereghino JJ, Gladding GD, Kupferberg HJ, Scoville B, White BG (1984) Antiepileptic Drug Development Program. Clev Clin 51:293-305

38. Krall RL, Penry JK, White BG, Kupferberg HJ, Swinyard EA (1978) Antiepileptic drug development: II. Anticonvulsant drug screening. Epilepsia 19:409-428

39. Stables JP, Kupferberg KJ (1997) In: Avanzini G, Tanganelli P, Avoli M (eds) Molecular and cellular targets for antiepileptic drugs. John Libbey, London, pp 191-198

40. Mulzac D, Scott KR (1993) Profile of anticonvulsant activity and minimal toxicity of methyl 4-[(p-chlorophenyl)amino]-6-methyl-2oxo-cyclohex-3-en-1-oate and some prototype antiepileptic drugs in mice and rats. Epilepsia 34:1141-1149

41. Yuzlenko O, Kieć-Kononowicz K (2008) Molecular modeling of $\mathrm{A}_{1}$ and $\mathrm{A}_{2 \mathrm{~A}}$ adenosine receptors: comparison of rhodopsin- and $\beta 2$-adrenergic-based homology models through the docking studies. J Comput Chem 30:14-32

42. Dore AS, Robertson N, Errey JC, Ng I, Hollenstein K, Tehan B, Hurrell E, Bennett K, Congreve M, Magnani F, Tate CG, Weir M, Marshall FH (2011) Structure of the adenosine $A_{2 \mathrm{~A}}$ receptor in complex with ZM241385 and the xanthines XAC and caffeine. Structure 19:1283-1293

43. Jaakola VP, Griffith MT, Hanson MA, Cherezov V, Chien EYT, Lane JR, Ijzerman AP, Stevens RC (2008) The 2.6 angstrom crystal structure of a human $\mathrm{A}_{2 \mathrm{~A}}$ adenosine receptor bound to an antagonist. Science 322:1211-1217
44. Kim SK, Gao ZG, Van Rompaey P, Gross AS, Chen A, Van Calenbergh S, Jacobson KA (2003) Modeling the adenosine receptors: comparison of the binding domains of $\mathrm{A}_{2 \mathrm{~A}}$ agonists and antagonists. J Med Chem 46:4847-4859

45. Ivanov AA, Barak D, Jacobson KA (2009) Evaluation of homology modeling of G-protein-coupled receptors in light of the $A_{2 A}$ adenosine receptor crystallographic structure. J Med Chem 52:3284-3292

46. Dal Ben D, Lambertucci C, Marucci G, Volpini R, Cristalli G (2010) Adenosine receptor modeling: what does the $A_{2 A}$ crystal structure tell us? Curr Top Med Chem 10:993-1018

47. White HS, Johnson M, Wolf HH, Kupferberg HJ (1995) The early identification of anticonvulsant activity: role of the maximal electroshock and subcutaneous pentylenetetrazol seizure models. Ital J Sci 16:73-77

48. Hockemeyer J, Burbiel JC, Müller CE (2004) Multigram-scale syntheses, stability, and photoreactions of $\mathrm{A}_{2 \mathrm{~A}}$ adenosine receptor antagonists with 8-styrylxanthine structure: potential drugs for Parkinson's disease. J Org Chem 69:3308-3318

49. Ozola V, Thorand M, Diekmann M, Qurishi R, Schumacher B, Jacobson KA, Müller CE (2003) 2-Phenylimidazo[2,1-i]purin-5ones: structure-activity relationships and characterization of potent and selective inverse agonists at human $\mathrm{A}_{3}$ adenosine receptors. Bioorg Med Chem 11:347-356

50. Bulicz J, Bertarelli DCG, Baumert D, Fülle F, Müller CE, Heber D (2006) Synthesis and pharmacology of pyrido[2,3-d] pyrimidinediones bearing polar substituents as adenosine receptor antagonists. Bioorg Med Chem 14:2837-2849

51. Klotz K-N, Hessling J, Hegler J, Owman C, Kull B, Fredholm BB, Lohse MJ (1998) Comparative pharmacology of human adenosine receptor subtypes - characterization of stably transfected receptors in CHO cells. Naunyn Schmiedeberg's Arch Pharmacol 357:1-9

52. Yan L, Bertarelli DCG, Hayallah AM, Meyer H, Klotz K-N, Müller CE (2006) A new synthesis of sulfonamides by aminolysis of p-nitrophenylsulfonates yielding potent and selective adenosine $\mathrm{A}_{2 \mathrm{~B}}$ receptor antagonists. J Med Chem 49:4384-4391

53. Bertarelli DCG, Diekmann M, Hayallah AM, Rüsing D, Iqbal J, Preiss B, Verspohl EJ, Müller CE (2006) Characterization of human and rodent native and recombinant adenosine $\mathrm{A}(2 \mathrm{~B})$ receptors by radioligand binding studies. Purinergic Signal 2:559571

54. Hayallah AM, Sandoval-Ramìrez J, Reith U, Schobert U, Preiss B, Schumacher B, Daly JW, Müller CE (2002) 1,8-Disubstituted xanthine derivatives: synthesis of potent $\mathrm{A}_{2 \mathrm{~B}}$-selective adenosine receptor antagonists. J Med Chem 45:1500-1510

55. Sauer R, Maurinsh J, Reith U, Fülle F, Klotz K-N, Müller CE (2000) Water-soluble phosphate prodrugs of 1-propargyl-8styrylxanthine derivatives, $\mathrm{A}_{2 \mathrm{~A}}$-selective adenosine receptor antagonists. J Med Chem 43:440-448

56. Maestro v.9.0, MacroModel v.9.7, Glide v.5.5; Schrödinger, LLC (2009) New York

57. PyMOL Molecular Graphics System v.0.99, DeLano Scientific 